\title{
Assessing spatial equity in access to service-provisioning hotspots in data- scarce tropical forests regions under external pressure
}

\author{
Sara O.I. Ramirez-Gomez ${ }^{\mathrm{a}, *}$, Frank van Laerhoven ${ }^{\mathrm{a}}$, René Boot ${ }^{\mathrm{b}, \mathrm{c}}$, Frank Biermann ${ }^{\mathrm{a}}$, \\ Pita A. Verweij ${ }^{\mathrm{a}}$ \\ ${ }^{a}$ Copernicus Institute of Sustainable Development, Faculty of Geosciences, Utrecht University, Vening Meineszgebouw A, Princetonlaan 8a, 3584 CB Utrecht, The \\ Netherlands \\ ${ }^{\mathrm{b}}$ Tropenbos International, Lawickse Allee 11, 6701 AN Wageningen, The Netherlands \\ ${ }^{\mathrm{c}}$ Ecology and Biodiversity Group, Department of Biology, Faculty of Science, Utrecht University. Hugo R. Kruytgebouw, Padualaan 8, 3584 CH Utrecht, The Netherlands
}

\section{A R T I C L E I N F O}

\section{Keywords:}

External pressures

Ecosystem services

Service-provisioning hotspots

Spatial equity

Conflicted space

Participatory GIS

\begin{abstract}
A B S T R A C T
Equity is an essential element in the implementation of policies related to ecosystem services. With the rapid expansion of commercial land use into tropical forest regions, the urgency and importance to integrate equity issues in space and time in decisions and actions stand without doubt. However, data scarcity in these regions limits the understanding of factors that affect spatial and temporal aspects of equity. This again emphasizes the need of rapid and robust ways to address spatio-temporal patterns of equity that are especially suited for datascarce regions. This study addresses this gap. We assess the factors that have an influence on spatial equity through an empirical study that compares two sub-regions in the Upper Suriname River Basin. In the first subregion, some logging and road building occur; the other, however, is more remote and such interventions are not yet developed but merely planned. We collected spatial data for 1995 and 2015 using a participatory GIS survey ( $n=493$ ), registering provisioning service hotspots. We then explored spatial equity, according to clan and authority position, by analyzing variation over time and across regions in relation to access capabilities of these users. In the region with roads and logging, spatial equity concerns emerged over time regarding the provision of timber and fish. In the remote region, spatial inequity in access to fish provisioning hotspots of ecosystem services increased while it showed a decreasing trend for timber. In outlining spatial equity concerns, we argue that spatial equity analysis unveils an essential social dimension in the use of the space that is integral in spatial planning processes in data scarce forest regions under external pressures.
\end{abstract}

\section{Introduction}

Tropical forests provide a variety of goods that form the base of rural livelihoods, such as food, water, timber, fibers, medicine and fuel. These goods, commonly referred to as provisioning ecosystem services, are used for both subsistence and commercial purposes (Shackleton and Shackleton, 2004) by different social groups (henceforth, 'user groups'). In common pool resources, the degree to which any individual, including traditional resource users, can use and benefit from these ecosystem services depends on complex mechanisms of access including social relationships, power, institutions, capabilities, rights and various capitals (Ribot and Peluso, 2003). Thus, there is a profound link between ecosystem service provision and equity as user groups with more capability to secure livelihood resources and income are in a more advantaged position than those user groups who have less capabilities
(Fisher et al., 2013). For example, some user groups might obtain more benefits from ecosystem services because they have better access capabilities on account of their high social status related to lineage, while other users belonging to a lower ethnic group might obtain less benefits (Lakerveld et al., 2015). Hence, equity involves recognizing that people have different capabilities and need different support and resources to ensure their rights are realized (Sikor and Nguyen, 2007).

As such, it is essential to consider equity in the implementation of policies related to ecosystem services, specifically if these policies are targeting the poor and the most disadvantaged people (Fisher et al., 2014). Following Brown and Corbera (2003), equity in relation to ecosystem services has three dimensions: equity in access, equity in decision-making and equity in outcome. Equity in access relates to the just opportunities that ecosystem service users may have to access and use ecosystem services. This depends on social status as well as on the

\footnotetext{
* Corresponding author.

E-mail address: soi.sararamirez@gmail.com (S.O.I. Ramirez-Gomez).
} 


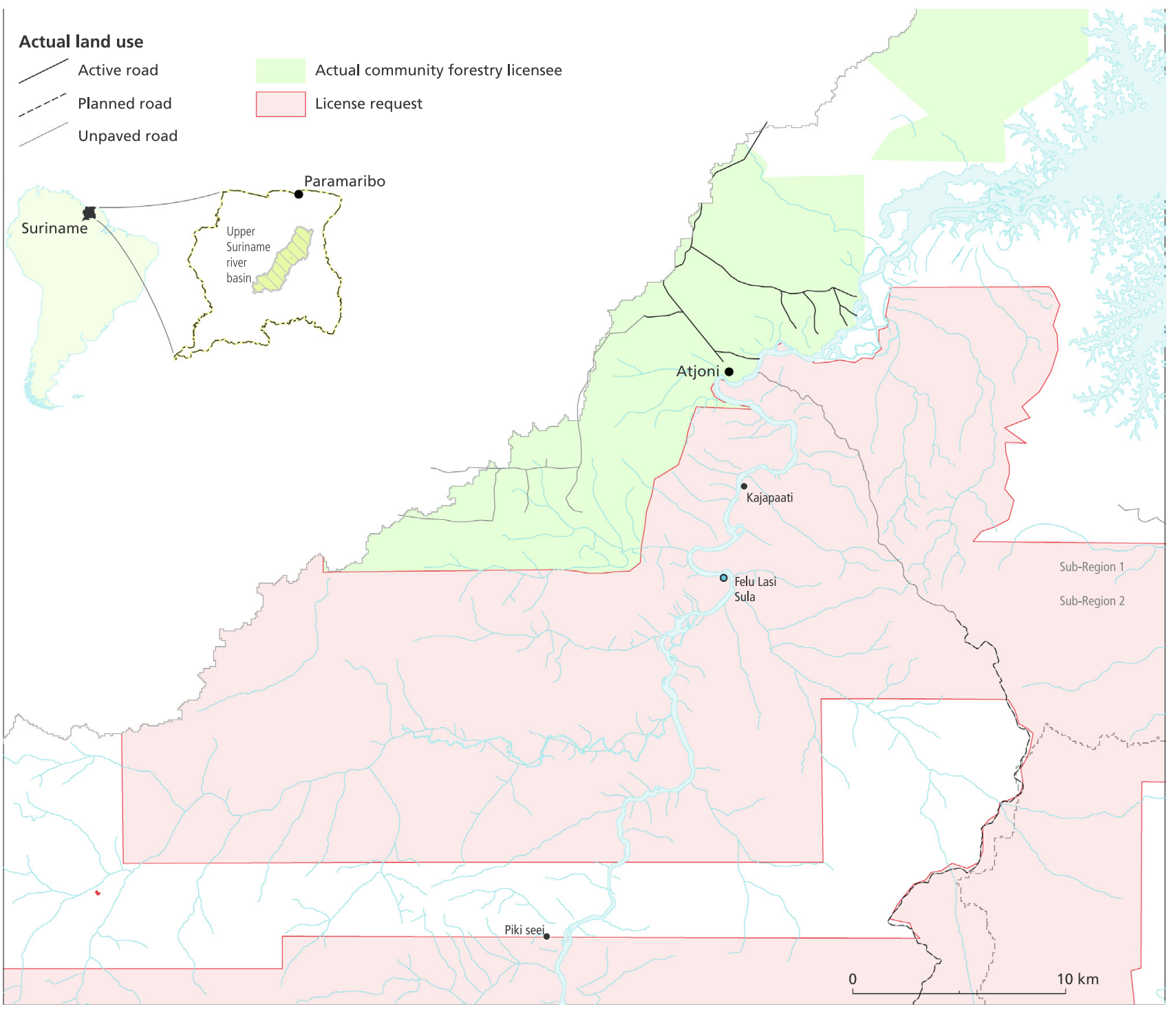

Fig. 1. Geographic location of the study area and overview of land use activities until 2015; sources: Stichting voor Bosbeheer en Bostoezicht -SBB- (2019).

Table 1

General characteristics of the study sub-regions.

\begin{tabular}{llllll}
\hline Study case & $\begin{array}{l}\text { Total area } \\
\text { (ha) }\end{array}$ & \multicolumn{2}{l}{ Population size } & & \multirow{2}{*}{$\begin{array}{l}\text { Total } \\
\text { respondents }\end{array}$} \\
\cline { 3 - 5 } & & 1997 & 2010 & 2015 & \\
\hline Upper Suriname & $1^{\prime} 267557$ & 13,045 & 17,254 & 18,502 & \\
$\quad$ River Basin & & & & & \\
Sub-region 1 & 177,231 &. & 2444 & 2553 & 238 \\
Sub-region 2 & 203,635 &. & 6221 & 6517 & 254 \\
\hline
\end{tabular}

* Source: Centraal Bureau voor Burgerzaken (CBB) (2019).

knowledge, capabilities and capitals, including both material and natural capital that users can have (Ifejika Speranza et al., 2014). Equity in decision-making concerns issues of recognition and inclusion of all views and needs in strategic management decision. Finally, equity in outcome refers to the fair distribution of ecosystem service benefits across users, which in turn depends on equity in access and in decisionmaking.

In this study, we address the first dimension, equity in access to ecosystem services and depart from the assumption that greater capabilities indicate more extensive means to use and derive higher benefits from ecosystem services, as suggested by Sikor and Nguyen (2007).
Therefore, according to Leach et al. (1999, page 232), access capabilities do not refer to "people's rights in a normative sense - what people should have - but the range of possibilities that people can have". Thus, asymmetries in the distribution of access capabilities among user groups can have equity implications in access to ecosystem services as also pointed out by Fisher et al. (2013, 2014).

\subsection{The spatial dimension of equity}

Equity in access to provisioning services is often studied in the context of social power dynamics that emerge in the flow of benefits from ecosystem services (Anderson et al., 2015; Barnaud and Van Paassen, 2013; Felipe-Lucia et al., 2015). However, since the production and use of ecosystem services has a strong spatial component (Syrbe and Walz, 2012), differences in access to locations where ecosystem services are produced can have important equity implications (Fisher et al., 2009). For example, in a local community context, those community members who have more capabilities might be able to access larger areas where ecosystem services are generated than other more marginalized user groups with a least range of capabilities (Rodríguez et al., 2006). Thus, by studying differences in spatial patterns of use of ecosystem services, other equity issues related to their spatial distribution can be unveiled (Bennett et al., 2015; de Groot 

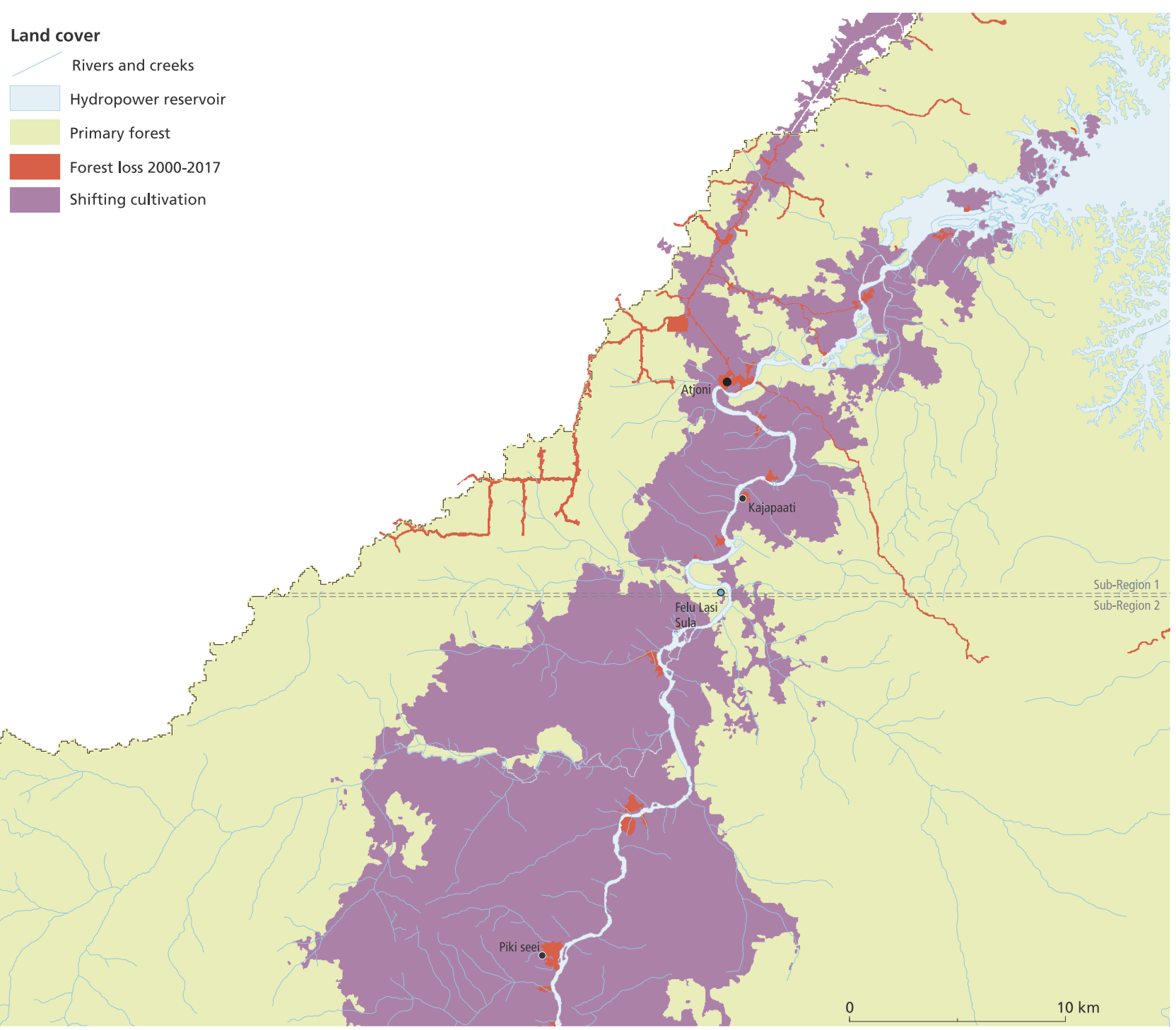

Fig. 2. Land cover types in the study areas.

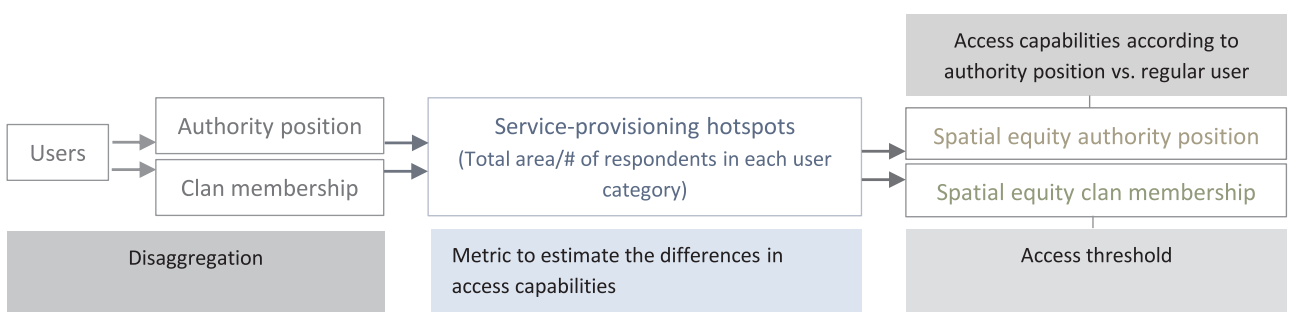

Fig. 3. Illustration of the operationalization steps of spatial equity studies.

et al., 2010). However, spatial patterns of equity in access to ecosystem services have remained largely unaddressed in data poor regions (Bennett and Chaplin-Kramer, 2016; Bennett et al., 2015; Birkhofer et al., 2015). Thus, metrics are needed to gain knowledge of important spatial and temporal equity issues in these regions. This study aims at addressing that gap by focusing on equity in access to the locations where ecosystem services are produced. We refer to this as spatial equity.

The study of spatial equity relies on the immediate need to bring equity analysis closer to the real-world problems and practice of land use planners and policy makers in tropical forest regions (Turkelboom et al., 2018). Land use policies aimed at opening up remote forest areas - e.g. in the form of infrastructure projects (roads, dams) followed by the promotion of commercial logging and mining - are often intended to ultimately have a net positive effect on the economy of a region. However, without detailed understanding of how land use development can affect the provision and use of ecosystem services, policy makers may be blind to the effects of these interventions on equity, in particular on spatial equity in access to important service-provisioning locations. This can be more acute in forest regions characterized by the scarcity of trustworthy and affordable data (Palomo et al., 2018). Without indicators that can be used to measure the impact that commercial land uses may have on spatial equity, it is likely that the impact of these intervention reinforce structural inequities in tropical forest regions.

As such, the aim of this paper is to develop and apply a participatory 
Table 2

Number of respondents per clan and authority position.

\begin{tabular}{lll}
\hline \multirow{2}{*}{ Clan identification number } & \multicolumn{2}{l}{ Number of respondents } \\
\cline { 2 - 3 } & Sub-region 1 & Sub-region 2 \\
\hline 1 & 4 & 142 \\
2 & 2 & 35 \\
3 & 19 & 25 \\
4 & 13 & 8 \\
5 & 121 & 5 \\
6 & 3 & 4 \\
7 & 26 & 4 \\
$8^{*}$ & 9 & $\mathrm{n} / \mathrm{a}$ \\
$9^{*}$ & 20 & $\mathrm{n} / \mathrm{a}$ \\
$10^{*}$ & 3 & $\mathrm{n} / \mathrm{a}$ \\
11 & 15 & 19 \\
$12^{* *}$ & $\mathrm{n} / \mathrm{a}$ & 3 \\
$13^{* *}$ & $\mathrm{n} / \mathrm{a}$ & 3 \\
Authority position & & \\
Chief & & 3 \\
Assistant chief & 4 & 10 \\
Dresimen & 13 & 4 \\
Regular ecosystem service user & $\mathrm{n} / \mathrm{a}$ & 237 \\
\hline
\end{tabular}

* Respondents belonging to these clans were only present in sub-region 1 .

** Respondents belonging to these clans were only present in sub-region 2 .

mapping methodology to operationalize the study of spatial equity in data-scarce tropical forest regions. We specifically address the question: Which factors affect spatial equity in tropical forest regions?

We studied the factors that have an influence on spatial equity by means of an empirical study that makes a comparison between two traditional communities in the Upper Suriname River Basin - one community affected by land use pressures in the form of road infrastructure developments and logging, and the other being affected to a much lesser extent. We operationalized our central research question and the assessment of spatial equity in this remote, data-scarce forest region in three steps. First, we disaggregated user groups in a manner that reflects different capabilities to access ecosystem services (e.g. chief, assistant chief, elderly people - Dresimen- or a regular ecosystem service user). Second, we identified spatial units that are collectively valued as highly important locations for ecosystem service provision (i.e. fish, timber and crops). We termed these locations service-provisioning hotspots (SPH) according to Palomo et al. (2013). These service-provisioning hotspots were interpreted as claimed areas of use that can be indicative of relative access. Third, we argue that spatial inequity occurs when the access capabilities to SPH between user groups are highly asymmetrical. In the discussion, we reflect on how the findings can support spatial planners and practitioners to consider spatial equity issues arising from the effects of land use interventions and from the use of space among traditional communities.

\section{Methods}

\subsection{Study area}

This study took place in the Upper Suriname River Basin that is located south from the Brokopondo dam, approximately $315 \mathrm{~km}$ south of Paramaribo, the capital of Suriname (Fig. 1). Afro-descendent people belonging to the Saramaka tribe, who are living in 64 villages along the river, inhabit the area. Traditionally, their livelihoods have been based on shifting cultivation, the collection of non-timber forest products, fishing and hunting. Since the construction of a major road in 2010, local communities have been increasingly involved in economic activities such as trade of timber and non-timber forests products, craft making and ecotourism. This study focuses on the basin area above the $4^{\circ}$ latitude, which is the Southern limit up to which timber concessions can be granted in Suriname (Stichting voor Bosbeheer en Bostoezicht, 2016). All land is formally owned by the state; therefore, none of the communities in the entire watershed holds legally recognized land rights to date.

Within that region, we selected two study sub-regions (Fig. 1). Subregion 1 has currently 60 kilometers of road extension, 32,600 hectares in active community forestry concessions, which are used in liaison with outsiders. Additionally, 37,424 hectares have been requested for community forestry concessions (Stichting voor Bosbeheer en Bostoezicht, 2019). These are areas where communal property rights are granted to manage timber and non-timber forest products (Bocci et al., 2018). According to official reports, the round wood production in sub-region 1 increased 90\% between 2010 and 2016 (Stichting voor Bosbeheer en Bostoezicht, 2016). This increase coincides with the pavement of the Atjoni road in 2010.

By contrast, sub-region 2 is more remote and has no road infrastructure nor granted community forest concessions, although community forestry applications covering 42,368 hectares have been submitted (Stichting voor Bosbeheer en Bostoezicht, 2019). A large rapid the Felu Lasi Sula that makes access to sub-region 2 difficult - marks the division between the regions. This de facto division of the basin is also made by local communities when working with outsiders, as the rapid functions as the gate to the most remote communities in the basin. Table 1 shows the general demographic aspects of the study area and the size of the sub-regions. Information about population size in each village of the Upper Suriname River Basin is only available from 2010 onwards.

\subsection{Local forest management and associated land use conflicts}

Sub-region 1 and sub-region 2 include 124,989 hectares of tropical primary forest and a fringe of 75,906 hectares of secondary forest along the river, originated because of regeneration after shifting cultivation

Table 3

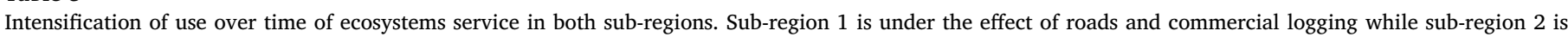

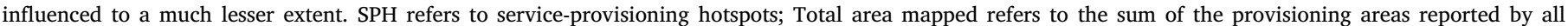
individual respondents before aggregating them into hotspots.

\begin{tabular}{|c|c|c|c|c|c|c|c|}
\hline \multirow[t]{2}{*}{ Service-provisioning Hotspots } & \multirow[t]{2}{*}{ Attribute } & \multicolumn{2}{|c|}{ Sub-region 1} & \multirow[t]{2}{*}{$\%$ of increase } & \multicolumn{2}{|c|}{ Sub-region 2} & \multirow[t]{2}{*}{$\%$ of increase } \\
\hline & & 1995 & 2015 & & 1995 & 2015 & \\
\hline \multirow[t]{3}{*}{ Fish } & Number of SPH & 1 & 5 & 400 & 5 & 9 & 80.0 \\
\hline & Total SPH area (ha) & 1033 & 1382 & 34 & 3357 & 3427 & 2.1 \\
\hline & Total area mapped (ha) & 48,788 & 55,353 & 13.5 & 87,852 & 139,848 & 59.2 \\
\hline \multirow[t]{3}{*}{ Timber } & Number of SPH & 8 & 34 & 325 & 2 & 10 & 400 \\
\hline & Total SPH area (ha) & 1231 & 2811 & 128.4 & 2772 & 3570 & 28.8 \\
\hline & Total area mapped (ha) & 33,251 & 44,484 & 33.8 & 85,604 & 132,953 & 55.31 \\
\hline \multirow[t]{3}{*}{ Crop } & Number of SPH & . & 19 & - & . & 25 & - \\
\hline & Total SPH area (ha) & - & 1319 & - & - & 2580 & - \\
\hline & Total area (ha, 2000)* & 12,767 & 27,295 & 113.8 & 31,459 & 101,085 & 221.3 \\
\hline
\end{tabular}

* Based on the forest cover map of the year 2000. Source:Stichting voor Bosbeheer en Bostoezicht (2019) 
Table 4

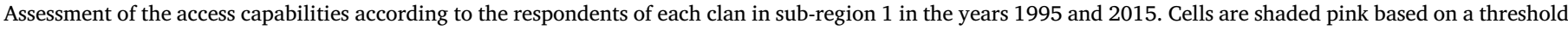

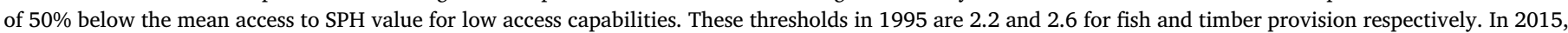

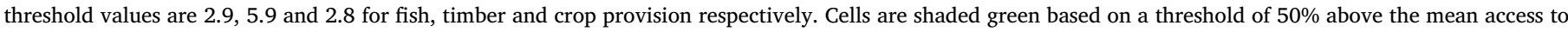

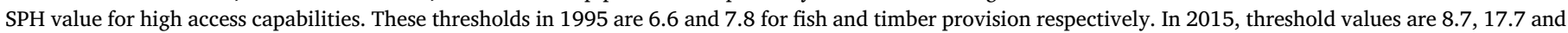
8.3 for fish, timber and crop provision respectively. Values falling within the range marked by these thresholds are left blank. $\mathrm{N}$ is the number of respondents.

\begin{tabular}{|c|c|c|c|c|c|c|c|}
\hline \multirow[t]{2}{*}{ User category } & \multirow[t]{2}{*}{ Ecosystem service } & \multirow[t]{2}{*}{$\mathbf{N}$} & \multirow{2}{*}{$\begin{array}{l}\% \text { of } \\
\text { responses }\end{array}$} & \multicolumn{2}{|c|}{ Total SPH (ha) } & \multicolumn{2}{|c|}{$\begin{array}{c}\text { Mean access to } \\
\text { SPH }\end{array}$} \\
\hline & & & & 1995 & 2015 & 1995 & 2015 \\
\hline \multirow{3}{*}{ All clans } & Fish & \multirow{3}{*}{238} & \multirow{3}{*}{100} & 1033 & 1382 & 4.4 & 5.8 \\
\hline & Timber & & & 1231 & 2811 & 5.2 & 11.8 \\
\hline & Crops & & & - & 1319 & - & 5.6 \\
\hline \multirow{3}{*}{ Clan 1} & Fish & \multirow{3}{*}{4} & \multirow{3}{*}{1.7} & 4 & 7 & 1.0 & 1.8 \\
\hline & Timber & & & 12 & 28 & 3.0 & 7.0 \\
\hline & Crops & & & - & 32 & - & 8.0 \\
\hline \multirow{3}{*}{ Clan 2} & Fish & \multirow{3}{*}{2} & \multirow{3}{*}{0.8} & 2 & 2 & 1.0 & 1.0 \\
\hline & Timber & & & 6 & 2 & 3.0 & 1.0 \\
\hline & Crops & & & - & 15 & - & 8.0 \\
\hline \multirow{3}{*}{ Clan 3} & Fish & \multirow{3}{*}{19} & \multirow{3}{*}{8.0} & 124 & 171 & 6.5 & 9.0 \\
\hline & Timber & & & 282 & 535 & 14.8 & 28.2 \\
\hline & Crops & & & - & 195 & - & 10.3 \\
\hline \multirow{3}{*}{ Clan 4} & Fish & \multirow{3}{*}{13} & \multirow{3}{*}{5.5} & 124 & 143 & 9.5 & 11.0 \\
\hline & Timber & & & 50 & 158 & 3.8 & 12.2 \\
\hline & Crops & & & - & 145 & - & 11.2 \\
\hline \multirow{3}{*}{ Clan 5} & Fish & \multirow{3}{*}{121} & \multirow{3}{*}{50.8} & 212 & 254 & 1.8 & 2.1 \\
\hline & Timber & & & 198 & 438 & 1.6 & 3.6 \\
\hline & Crops & & & - & 228 & - & 1.9 \\
\hline \multirow{3}{*}{ Clan 6} & Fish & \multirow{3}{*}{3} & & 30 & 88 & 10.0 & 29.3 \\
\hline & Timber & & 1.3 & 31 & 75 & 10.3 & 25.0 \\
\hline & Crops & & & - & 19 & - & 6.3 \\
\hline & Fish & & & 106 & 107 & 4.0 & 4.0 \\
\hline Clan 7 & Timber & 26 & 10.9 & 254 & 958 & 9.8 & 36.8 \\
\hline & Crops & & & - & 150 & - & 5.8 \\
\hline & Fish & & & 137 & 185 & 15.2 & 20.6 \\
\hline Clan $8 *$ & Timber & 9 & 3.8 & 88 & 257 & 9.8 & 28.6 \\
\hline & Crops & & & - & 199 & - & 22.1 \\
\hline & Fish & & & 96 & 106 & 4.8 & 5.3 \\
\hline Clan 9* & Timber & 20 & 8.4 & 259 & 260 & 13.0 & 13.0 \\
\hline & Crops & & & - & 86 & - & 4.3 \\
\hline & Fish & & & 33 & 56 & 11.0 & 18.7 \\
\hline Clan $10^{*}$ & Timber & 3 & 1.3 & 6 & 15 & 2.0 & 5.0 \\
\hline & Crops & & & - & 7 & - & 2.3 \\
\hline & Fish & & & 165 & 263 & 11.0 & 17.5 \\
\hline Clan 11 & Timber & 15 & 6.3 & 45 & 85 & 3.0 & 5.7 \\
\hline & Crops & & & - & 243 & - & 16.2 \\
\hline
\end{tabular}

* Responses from these clans were only recorded in sub-region 1.

(Fig. 2). In the entire watershed, forest management has been traditionally based on customary laws which distribute forest lands over clans and according to which the individuals belonging to a particular clan enjoy subsidiary use and occupation rights (Price, 1975). Community members of the Saramaka tribe are distributed in 12 clans: Awana, Abaisa, Bakapau, Biitu, Dombi, Fandaaki, Langu, Matjau, Nasi, Nyafai, Paputu and Watambii. In addition, in the Saramaka river basin there are a few people from the Matawaii tribe, who are originally from the Western neighboring basin. Therefore, in total, this study had responses from 13 clans. Some clans tend to have more influence than others depending on the perceived spiritual relations with ancestors, the land and kinship structures (Price, 2002). The formal socio-political structure of the Saramaka tribe includes a Granman (tribal chief) and village chiefs (Kapiteins) who are assisted by several assistant chiefs and elderly people locally known as Dresimen. The government appoints the chiefs and the assistant chiefs; their position is for life and they receive a wage.

The concession of areas for community forestry rights is based on the laws and regulations stated in the Forest Management Act of 1992. Applications to community forestry concessions need to be made by the tribal chief (Granman) or by a village chiefs (Kapiteins). Local narrative suggested that land use conflict emerge among clans when a traditional authority belonging to a certain clan requests and gets granted a concession as this often spatially overlap with the forest occupation rights of other clans. Similarly, in both sub-regions there is hierarchy and power within the communities according to clan membership and authority position, which is often exacerbated by their ability and position to liaise with outsiders (i.e. logging companies together with whom local authorities exploit concession area). This has created unequal outcomes among from community forestry activities due the wellknown phenomena of elite capture (Iversen et al., 2006). 
Table 5

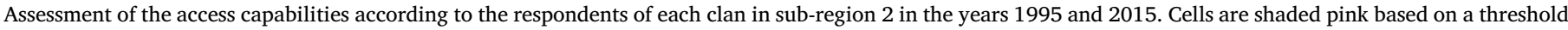

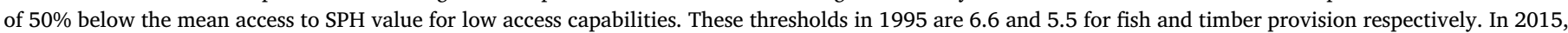

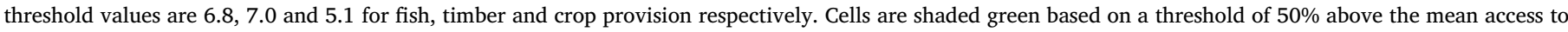

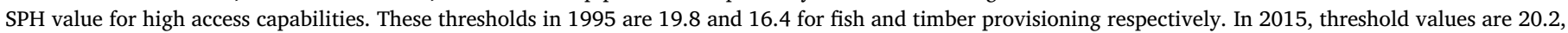

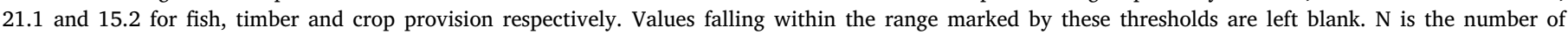
respondents.

\begin{tabular}{|c|c|c|c|c|c|c|c|}
\hline \multirow{2}{*}{ User category } & \multirow{2}{*}{$\begin{array}{c}\text { ES } \\
\text { provision }\end{array}$} & \multirow{2}{*}{$\mathbf{N}$} & \multirow{2}{*}{$\begin{array}{c}\% \text { of } \\
\text { responses }\end{array}$} & \multicolumn{2}{|c|}{ Total SPH (ha) } & \multicolumn{2}{|c|}{ Mean access to SPH } \\
\hline & & & & 1995 & 2015 & 1995 & 2015 \\
\hline \multirow{3}{*}{ All clans } & Fish & \multirow{3}{*}{254} & \multirow{3}{*}{100} & 3357 & 3427 & 13.2 & 13.5 \\
\hline & Timber & & & 2772 & 3570 & 10.9 & 14.1 \\
\hline & Crops & & & - & 2580 & - & 10.2 \\
\hline \multirow{3}{*}{ Clan 1} & Fish & \multirow{3}{*}{142} & \multirow{3}{*}{55.9} & 604 & 416 & 4.3 & 2.9 \\
\hline & Timber & & & 450 & 606 & 3.2 & 4.3 \\
\hline & Crops & & & - & 222 & - & 1.6 \\
\hline \multirow{3}{*}{ Clan 2} & Fish & \multirow{3}{*}{35} & \multirow{3}{*}{13.8} & 822 & 301 & 23.5 & 8.6 \\
\hline & Timber & & & 273 & 624 & 8.0 & 18.0 \\
\hline & Crops & & & - & 1124 & - & 32.1 \\
\hline \multirow{3}{*}{ Clan 3} & Fish & \multirow{3}{*}{25} & \multirow{3}{*}{9.8} & 625 & 350 & 25.0 & 14.0 \\
\hline & Timber & & & 466 & 380 & 18.6 & 15.2 \\
\hline & Crops & & & - & 242 & - & 9.7 \\
\hline \multirow{3}{*}{ Clan 4} & Fish & \multirow{3}{*}{8} & \multirow{3}{*}{3.1} & 287 & 643 & 35.9 & 80.4 \\
\hline & Timber & & & 506 & 672 & 63.3 & 84.0 \\
\hline & Crops & & & . & 71 & - & 8.9 \\
\hline \multirow{3}{*}{ Clan 5} & Fish & \multirow{3}{*}{5} & \multirow{3}{*}{2.0} & 322 & 254 & 64.4 & 50.8 \\
\hline & Timber & & & 140 & 203 & 28.0 & 40.6 \\
\hline & Crops & & & - & 125 & - & 25.0 \\
\hline \multirow{3}{*}{ Clan 6} & Fish & \multirow{3}{*}{4} & \multirow{3}{*}{1.6} & 94 & 110 & 23.5 & 27.5 \\
\hline & Timber & & & 33 & 251 & 8.3 & 62.8 \\
\hline & Crops & & & - & 41 & - & 10.3 \\
\hline \multirow{3}{*}{ Clan 7} & Fish & & & 20 & 388 & 5.0 & 97.0 \\
\hline & Timber & 4 & 1.6 & 20 & 24 & 5.0 & 6.0 \\
\hline & Crops & & & - & 6 & - & 1.5 \\
\hline & Fish & & & 356 & 569 & 18.7 & 29.9 \\
\hline Clan 11 & Timber & 19 & 7.5 & 567 & 542 & 29.8 & 28.5 \\
\hline & Crops & & & - & 455 & - & 23.9 \\
\hline & Fish & & & 52 & 43 & 17.3 & 14.3 \\
\hline Clan $12 * *$ & Timber & 3 & 1.2 & 76 & 92 & 25.3 & 30.7 \\
\hline & Crops & & & - & 82 & - & 27.0 \\
\hline & Fish & & & 175 & 353 & 58.3 & 117.7 \\
\hline Clan $13 * *$ & Timber & 3 & 1.2 & 241 & 174 & 80.3 & 58.0 \\
\hline & Crops & & & - & 212 & - & 70.7 \\
\hline
\end{tabular}

${ }^{* *}$ Responses from these clans were only recorded in sub-region 2 .

\subsection{Selected ecosystem services and their users}

The ecosystem services included in this study are the provision of fish, timber and crops. We made this selection based on a prioritization exercise within the scope of the overall research project in which the present study is embedded (see Ramirez-Gomez et al., 2017 for details). Furthermore, we define ecosystem service users as individuals or groups of people who benefit from using specific services that ecosystems provide (Plieninger et al., 2013). In this study we made a distinction by ethnic clans and by authority position according to four levels: 1) chiefs, 2) assistant chiefs, 3) elderly people (or Dresimen) and 4) regular community members. This distinction was based on the result of focus groups and community discussions (for details see Ramirez-Gomez et al., 2017). Among these groups, access to ecosystem services is often determined according to a customary land zoning which divide forest areas according to clan membership.

\subsection{Data collection}

Data was collected through a participatory Geographic Information System (PGIS) survey among community members, which was conducted between November 2015 and February 2016 by a team of three interviewers and one field coordinator. The sample population was selected using a snowball approach (Newing et al., 2010). First, the field coordinator asked the village authority to provide a list of 20 names trying to balance gender (50:50 if possible) and age (an age $\geq 31$ years was chosen to make sure that respondents would be able to provide ES information from the last 20 years). The people selected were interviewed first and subsequently, interviewers asked each respondent to nominate additional respondents. In total, 492 responses were collected, 238 in sub-region 1 and 254 in sub-region 2. The PGIS survey built on previous participatory mapping activities described in detail in Ramirez-Gomez et al. (2017). The map produced during that study depicted land use and land cover information for the year 2015 and it was used as the base map during the PGIS survey. For the field interviews, this map was printed in A3 format and overlaid with 


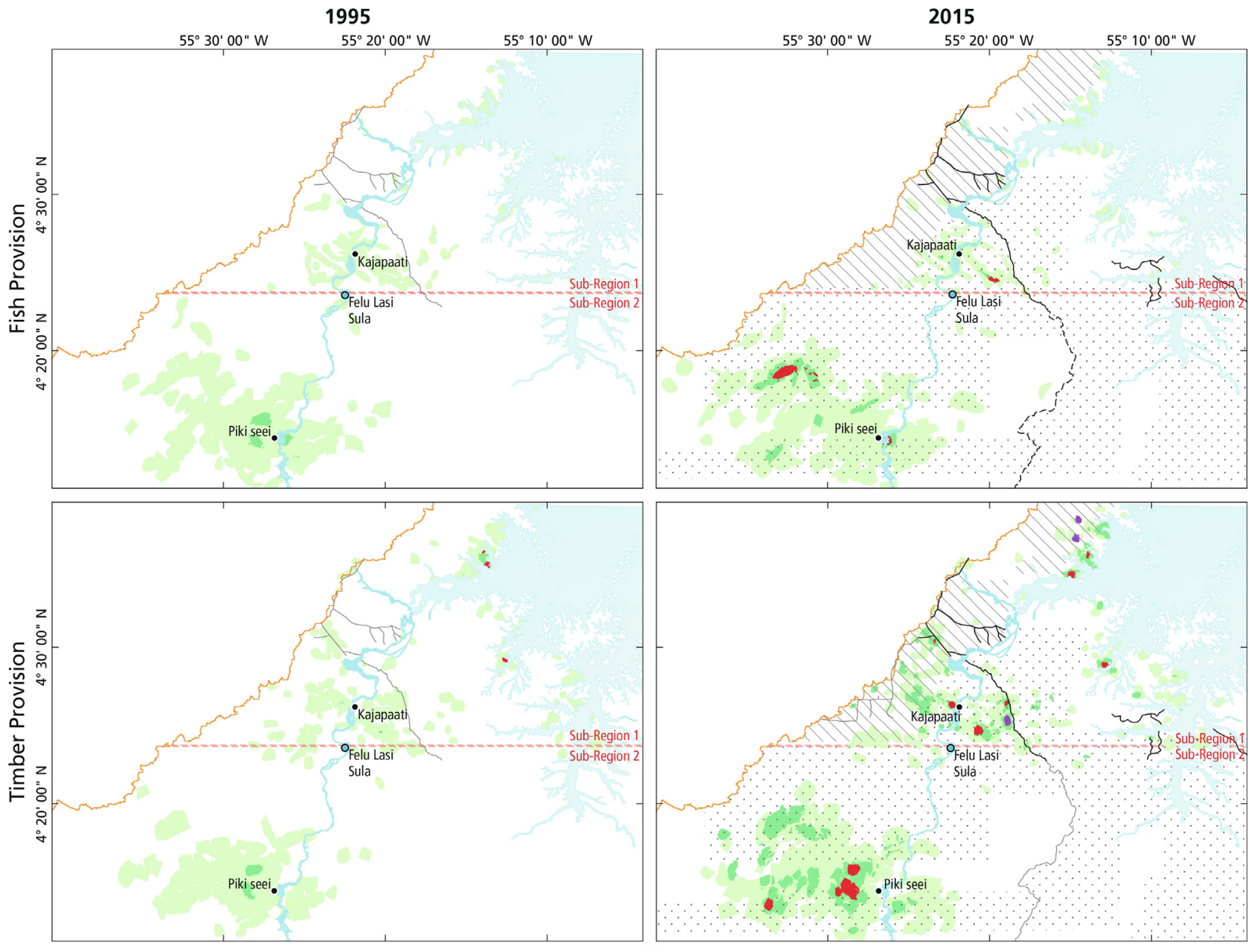

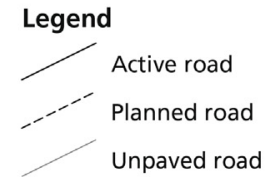

Service Provisioning

Total area mapped

Hotspots (SPH)

Areas subject to conflict

Among clans

Authority position

\section{Forestry concessions}

Actual community forestry license

License request

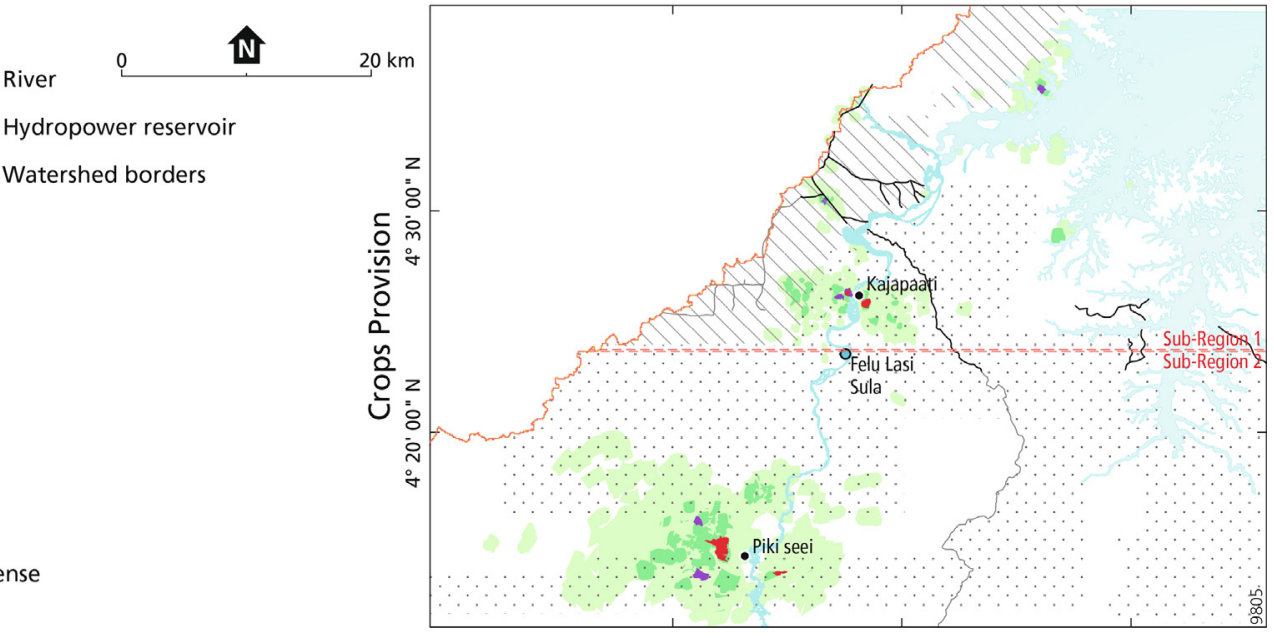

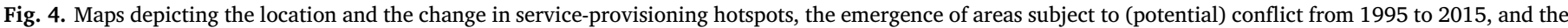

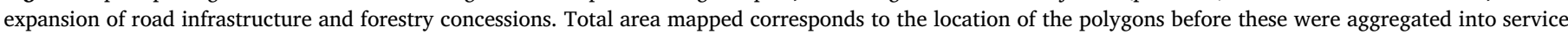

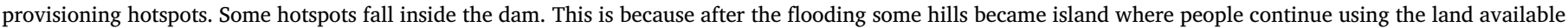
there.

transparent sheets having a geographical grid as a reference. Respondents were asked: "Could you please show in the [base] map the three main locations where you go fishing, where you harvest timber and the three main locations for crops?, could you please indicate using different color markers, these main locations in the past (20 years ago) and then in the present?" Only the locations for the provision of fish and timber were identified for 1995 . There is no crop data preceding 2015. During the interviews, the respondents indicated that the location of crops remained largely the same over the last 20 years, as these have been semi-permanent and have remained within walking distance from the main village. This system is referred to as "Pikien Kapee", and is characterized by short fallow periods (less than 15 years). The 
Table 6

Trend in the Gini coefficient in 1995 and 2015 in relation to clan user's capabilities to access service-provisioning hotspots in both sub-regions. A value $\geq 0.4$ is indicative of spatial inequity. Sub-region 1 is under the influence of land use pressure i.e. logging and road development while sub-region 2 is influenced to a lesser extent.

\begin{tabular}{lllll}
\hline Sub-watershed & \multirow{2}{*}{ Number of clans } & Ecosystem service & \multicolumn{2}{l}{ Gini coefficient } \\
\cline { 4 - 5 } & & & 1995 & 2015 \\
\hline \multirow{2}{*}{ Sub-region 1 } & \multirow{2}{*}{11} & Fish provision & 0.37 & 0.45 \\
& & Timber provision & 0.34 & 0.43 \\
Sub-region 2 & \multirow{2}{*}{10} & Crop provision & - & 0.31 \\
& & Fish provision & 0.37 & 0.47 \\
& & Timber provision & 0.47 & 0.40 \\
& & Crop provisioning & - & 0.47 \\
\hline
\end{tabular}

communities in the study area cultivate less in primary forest because it is remote; farmers and their families have to stay there for longer periods (weeks) and they cannot do that anymore because their children attend school.

\subsubsection{Ethic statement}

Data collection methods were in line with the Code of Conduct for working with Indigenous and Local Communities of Tropenbos International (Persoon and Minter, 2011). Before beginning the survey, potential respondents were informed of the goal of the interviews through a statement read by the interviewers who assured that the data would be analyzed anonymously. Interviews were conducted with
Table 7

Summary of areas subject to conflicting claims between ecosystem service users. These areas are the result of the overlap between users with high vs. low degree of access to service provisioning hotspots. Sub-region 1 is under the influence of logging and roads; sub-region 2 to a lesser extent as these interventions are not yet developed in this region.

\begin{tabular}{|c|c|c|c|c|c|}
\hline \multirow{2}{*}{$\begin{array}{l}\text { Service Provisioning } \\
\text { Hotspots }\end{array}$} & \multirow[t]{2}{*}{ Attribute } & \multicolumn{2}{|c|}{ Sub-region 1} & \multicolumn{2}{|c|}{ Sub-region 2} \\
\hline & & 1995 & 2015 & 1995 & 2015 \\
\hline \multirow[t]{2}{*}{ Fish } & $\begin{array}{l}\text { Number of areas of } \\
\text { potential conflict }\end{array}$ & 0 & 1 & 0 & 4 \\
\hline & Total size (ha) & 0 & 36 & 0 & 602 \\
\hline \multirow[t]{2}{*}{ Timber } & $\begin{array}{l}\text { Number of areas of } \\
\text { potential conflict }\end{array}$ & 2 & 10 & 0 & 3 \\
\hline & Total size (ha) & 44 & 287 & 0 & 376 \\
\hline \multirow[t]{2}{*}{ Crop } & $\begin{array}{l}\text { Number of areas of } \\
\text { potential conflict }\end{array}$ & . & 1 & . & 2 \\
\hline & Total size (ha) & . & 44 & . & 57 \\
\hline
\end{tabular}

voluntary respondents following a verbal and written consent from the potential respondents who also indicated whether they would like to be contacted for the presentation of the results of the analysis.

\subsection{Operationalization of spatial equity analysis}

To operationalize the study of spatial equity we undertook three steps, which are summarized in, Fig. 3.

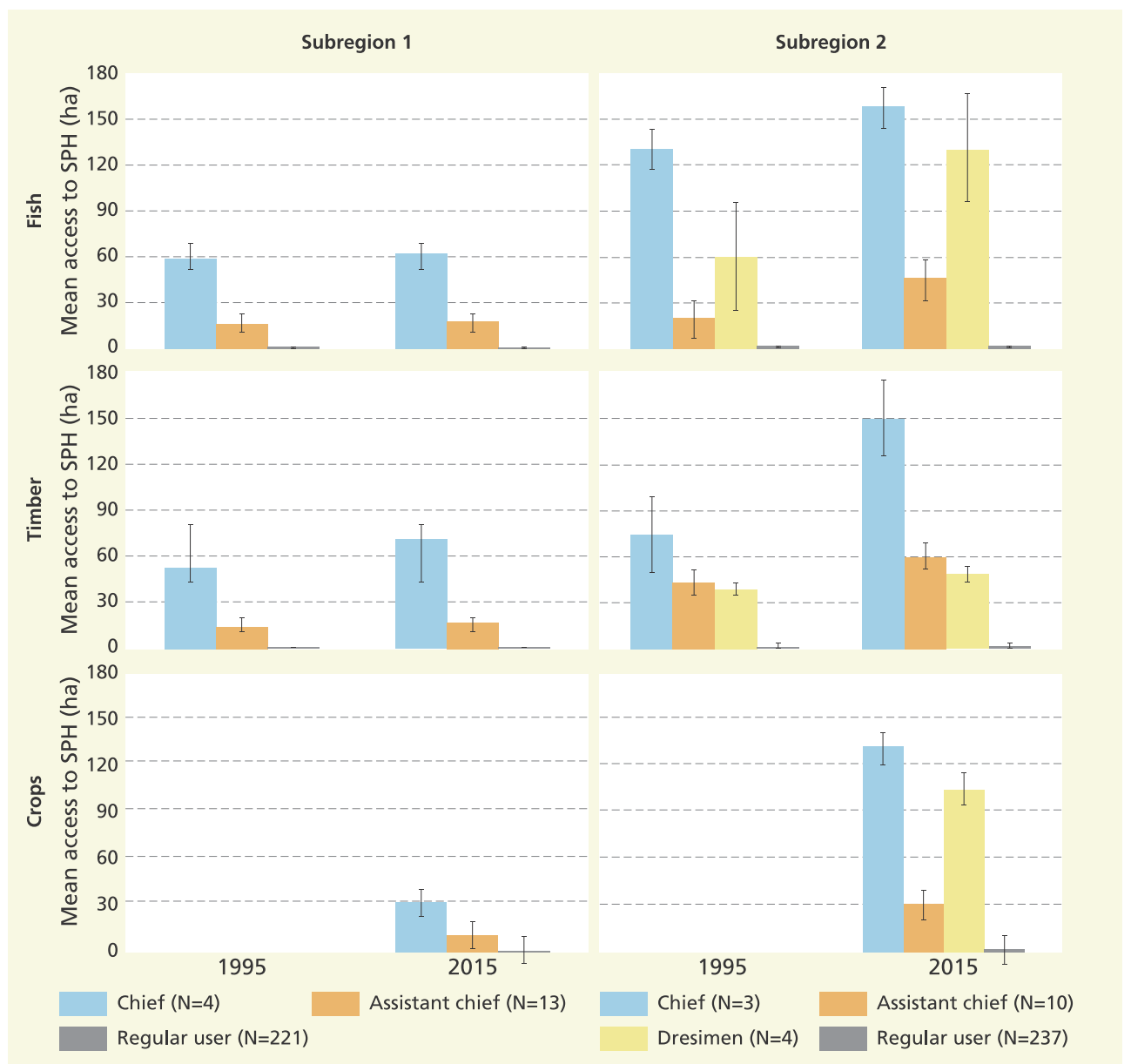

Fig. 5. Spatial equity as derived from the mean access to SPH according to different authority positions. Sub-region 1 is under the influence of land use pressures i.e. logging and road development, while sub-region 2 is influenced to a lesser extent. Dresimen was only reported in sub-region 2. 


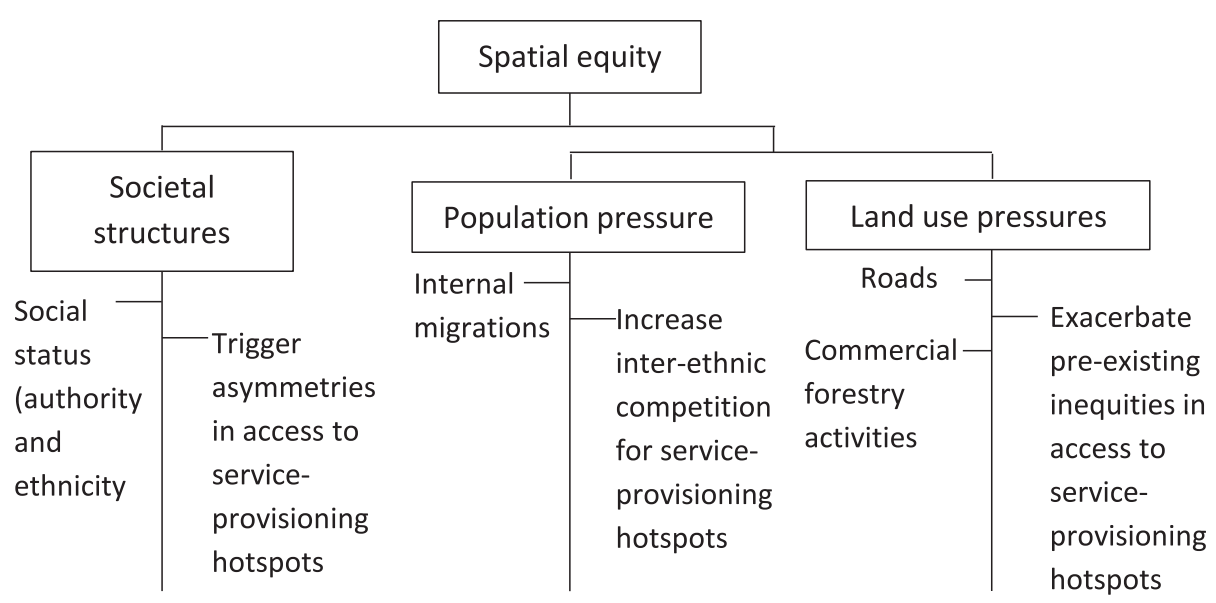

Fig. 6. Main factors found to influence spatial equity in this study.

Table A1

Mean access to Service provision hotspots (SPH) for level of authority in Sub-region 1 in the period 1995 and 2015.

\begin{tabular}{|c|c|c|c|c|c|c|}
\hline \multirow[t]{2}{*}{ User category } & \multirow{2}{*}{$\begin{array}{l}\text { Ecosystem } \\
\text { service }\end{array}$} & \multirow[t]{2}{*}{$\mathrm{N}$} & \multicolumn{2}{|c|}{ Total SPH (ha) } & \multicolumn{2}{|c|}{ Mean access to SPH } \\
\hline & & & 1995 & 2015 & 1995 & 2015 \\
\hline \multirow[t]{3}{*}{ Capitein } & Fish & 4 & 233 & 251 & 58.3 & 62.3 \\
\hline & Timber & & 215 & 285 & 53.3 & 71.3 \\
\hline & Crops & & $\cdot$ & 129 & $\cdot$ & 25.8 \\
\hline \multirow[t]{3}{*}{ Assistant capitein } & Fish & 13 & 208 & 230 & 16.0 & 17.7 \\
\hline & Timber & & 188 & 226 & 14.5 & 17.4 \\
\hline & Crops & & $\cdot$ & 119 & $\cdot$ & 9.2 \\
\hline \multirow{3}{*}{$\begin{array}{r}\text { No authority } \\
\text { function }\end{array}$} & Fish & 221 & 199 & 227 & 0.9 & 1.0 \\
\hline & Timber & & 136 & 181 & 0.6 & 0.8 \\
\hline & Crops & & $\cdot$ & 111 & $\cdot$ & 0.5 \\
\hline
\end{tabular}

Table A2

Mean access to Service provision hotspots (SPH) for level of authority in Sub-region 2 in the period 1995 and 2015.

\begin{tabular}{|c|c|c|c|c|c|c|}
\hline \multirow[t]{2}{*}{ User category } & \multirow{2}{*}{$\begin{array}{l}\text { Ecosystem } \\
\text { service }\end{array}$} & \multirow[t]{2}{*}{$\mathrm{N}$} & \multicolumn{2}{|c|}{ Total SPH (ha) } & \multicolumn{2}{|c|}{ Mean access to SPH } \\
\hline & & & 1995 & 2015 & 1995 & 2015 \\
\hline \multirow[t]{3}{*}{ Capitein } & Fish & 3 & 392 & 473 & 130.6 & 157.6 \\
\hline & Timber & & 224 & 450 & 74.6 & 150.0 \\
\hline & Crops & & $\cdot$ & 396 & $\cdot$ & 132.0 \\
\hline \multirow{3}{*}{$\begin{array}{l}\text { Assistant } \\
\text { capitein }\end{array}$} & Fish & 10 & 204 & 459 & 20.4 & 45.9 \\
\hline & Timber & & 429 & 599 & 42.9 & 59.9 \\
\hline & Crops & & $\cdot$ & 311 & $\cdot$ & 31.1 \\
\hline \multirow[t]{3}{*}{ Dresimen } & Fish & 4 & 240 & 518 & 60 & 129.5 \\
\hline & Timber & & 154 & 194 & 38.5 & 48.5 \\
\hline & Crops & & $\cdot$ & 426 & $\cdot$ & 106.5 \\
\hline \multirow{3}{*}{$\begin{array}{r}\text { No authority } \\
\text { function }\end{array}$} & Fish & 237 & 359 & 536 & 1.5 & 2.26 \\
\hline & Timber & & 334 & 379 & 1.4 & 1.6 \\
\hline & Crops & & $\cdot$ & 388 & $\cdot$ & 1.6 \\
\hline
\end{tabular}

\subsubsection{Disaggregation of ecosystem service users}

PGIS survey respondents were divided according to 13 clans and 4 authority positions mentioned above. For ethical reasons, we refrain from naming the clans in this study but provide a number to identify them. Table 2 presents the number of respondents per clan and authority position in each sub-region. The exact size of each clan is unknown. However, the number of respondents is indicative of estimated clan sizes. For example, clan 1 and clan 5 are the largest common clans in the entire basin (Price, 2002) and as such, they have the largest representation in the responses.

\subsubsection{Identification of service-provisioning hotspots}

The transparent sheets containing the raw PGIS information were scanned; georeferenced and polygons indicating locations where ecosystem services are provided to individual respondents were digitized and stored in ArcGIS ${ }^{\circledast}$. To identify service-provisioning hotspots, these polygons where overlapped using a customized GIS tool (RamirezGomez and Martínez, 2013) that counts the number of overlapping areas. This resulted in polygon density maps for each ecosystem service. For each density map, we identified hotspot locations by applying a heuristic cut-off value equal to the third quartile of the polygon density distribution. This was in line with procedures applied in other studies (e.g. Ramirez-Gomez et al., 2016; Ramirez-Gomez et al., 2015; Brown and Pullar, 2012). Service-provisioning hotspots were mapped and classified for the past (1995) and present (2015), except for crops (only for 2015). However, to address the lack of primary historic data for crop 
Table A3

Calculation of Gini Coefficient among clans for fish provision in 1995, sub-region 1.

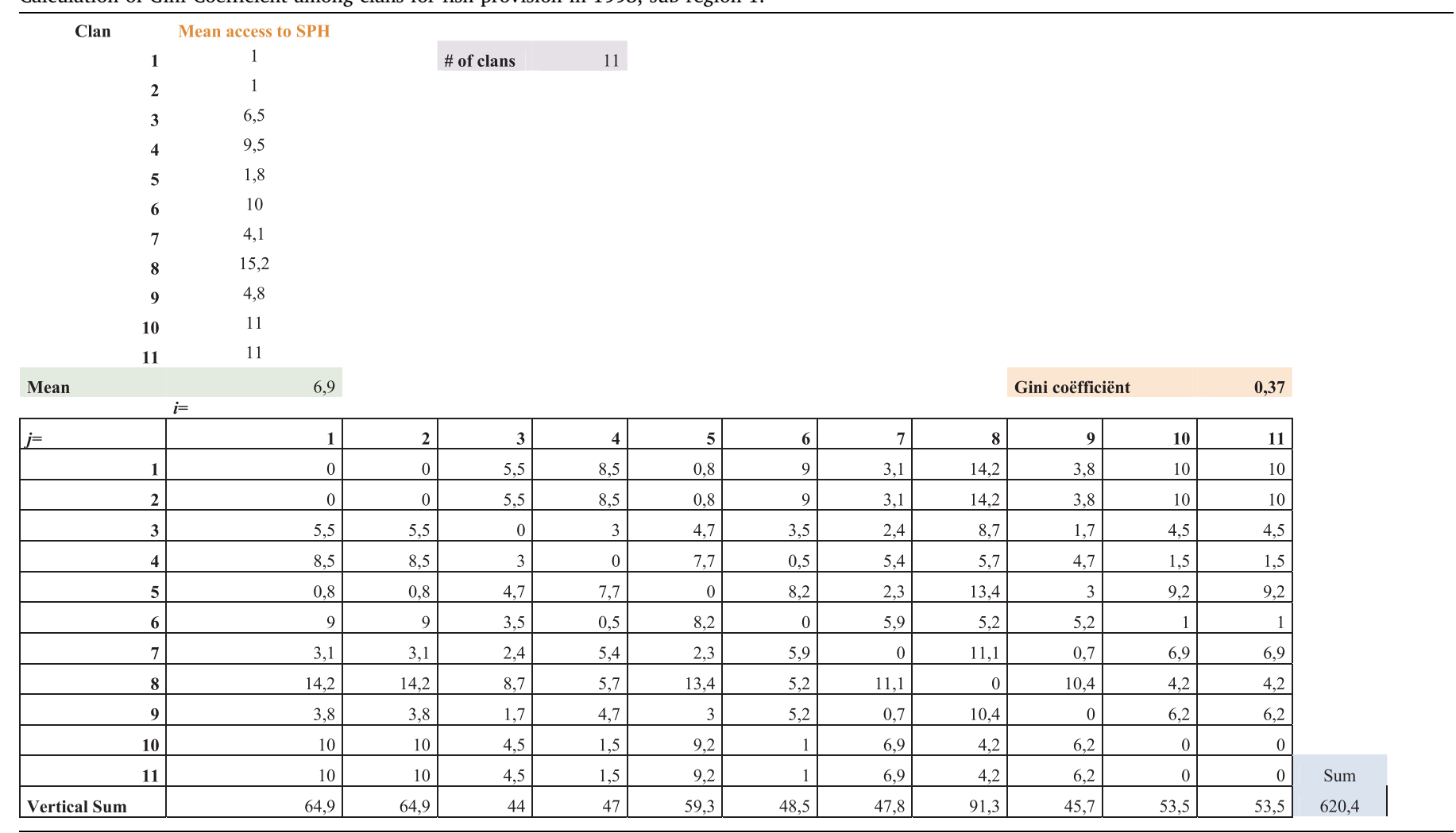

provisioning, we compared our data from 2015 to the size of the areas in crops derived from the available forest cover map of 2000 (Stichting voor Bosbeheer en Bostoezicht, 2019). For both 1995 and 2015, an attribute table was built for each service- provisioning hotspot containing information about size in hectares, as well as clan membership and authority position of the respective users (respondents). To gain insight in the development of the intensity of use over time, we compared the increase in number and size of the service-provisioning hotspots in each sub-region.

2.5.2.1 Mean access to service-provisioning hotspots. To address mean access to SPH, we first calculated how the total area of serviceprovisioning hotspots per ecosystem service was distributed across clans and authority position in 1995 and in 2015 in each sub-region. The formula used to estimate this access was:

Mean access to $\mathrm{SPH}$ [clan,authority]

$$
=\frac{\text { Total SPH area mapped per ES user (group) }}{\# \text { of respondents in each category }}
$$

where ES is ecosystem services and SPH is service-provisioning hotspots.

We use the result of this calculation to assess the differences in access capabilities within user groups, thus it was calculated individually for each respondent belonging to a certain clan and to certain authority position. Our assumption is that larger claims over service-provisioning hotspots are indicative of higher access capabilities. We based this assumption on various scholars (Fisher et al., 2014; Ifejika Speranza et al., 2014; Leach et al., 1999) who highlighted that the amount of natural capital a user is able to claim provides an indication of the access capabilities of the resource users. 2.5.3.1 Spatial equity according to clan membership. To assess spatial equity according to clan membership, we first assessed how asymmetrical the respondents' access capabilities to service provisioning hotspots were. To identify those clan respondents having high access capabilities versus clan respondents with lower capabilities of access to service-provisioning hotspots, we set a heuristic upper limit of $50 \%$ above the mean access to SPH. For low access capabilities, we set a heuristic limit of $50 \%$ below the mean access to SPH. This analysis was completed for two points in time corresponding to the years 1995 and 2015 for the provision of fish and timber and 2015 for the provision of crops. Highly skewed distributions of access capabilities were indicative of spatial equity concerns as suggested by Sikor and Nguyen (2007).

Additionally, to understand spatial equity among clans and between sub-regions, we calculated the Gini coefficient index. The Gini coefficient is a commonly used summary measure of inequity of income. It can also be applied to measure inequities in other resource distributions (Druckman and Jackson, 2008). In this study, we applied it to measure the extent of spatial equity in the access to fish, timber and crops provisioning hotspots among clans in each sub-region. We calculated it for 1995 and 2015 using the mean access value to SPH per clan, based on the following formula:

$\mathrm{GC}=\frac{1}{2 \mathrm{n}^{2} \mu} \sum_{j=1}^{n} \sum_{i=1}^{n}\left|y_{j}-y_{i}\right|$

where $\mathrm{n}$ is the number of clans in the sample, $\mathrm{y}_{\mathrm{i}}$ is the SPH extent of clan $\mathrm{i}($ clan $1,2,3, \ldots, \mathrm{n})$ and $\mu$ is the arithmetic mean of SPH extent among all clans.

The value of the Gini Coefficient varies from 0 to 1 . According to general international standards, a Gini Coefficient that is smaller than 0.3 represents a particularly equitable situation, values from 0.3 to 0.4 a common situation, while values greater than 0.4 raise concern, and a value greater than 0.6 indicates a problematic state (Jin et al., 2015). Details of the calculation are presented in Tables A3-A12. 
Table A4

Calculation of Gini Coefficient among clans for fish provision in 2015, sub-region 1 .

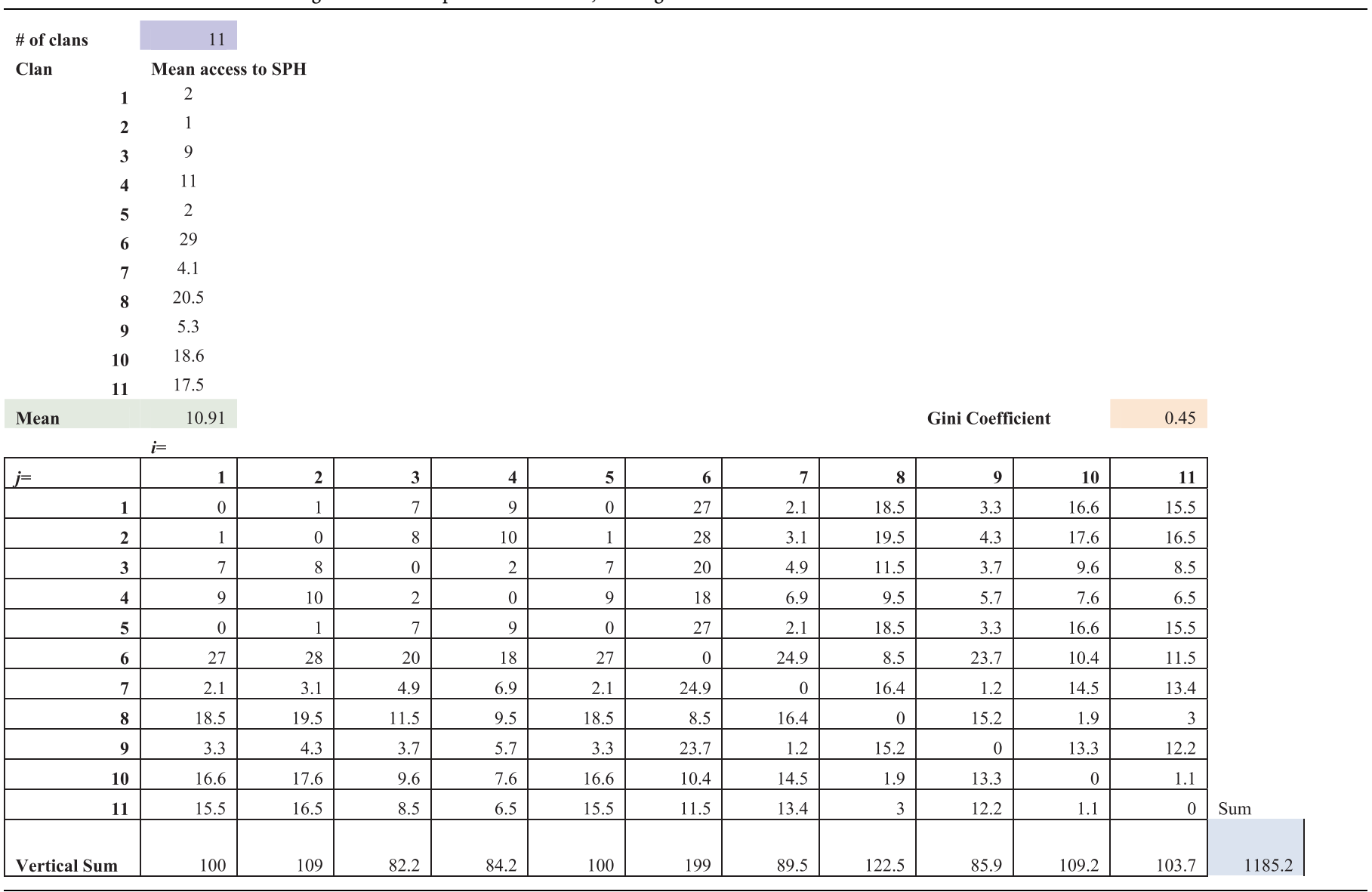

2.5.3.2 Spatial equity according to authority position. To assess spatial equity across authority position, we compared how access to SPH is distributed among chiefs, assistant chiefs, and Dresimen, in contrast to regular ecosystem service users (Tables A1 and A2). We assume that spatial inequity occurs when the few users with a high status present more access capabilities than all other user groups.

\subsection{Locations with potential conflict among users groups with different access to hotspot locations}

To identify areas subject to potential conflict we selected from Tables 4 and 5, the users who reported the largest access capabilities and the users who reported the lowest access capabilities (who turned out to be the majority of the respondents) according to the thresholds established in Section 3.5 c. We performed a spatial overlay of these users by using the intersect tool in ArcMap ${ }^{\circledR}$. This spatial overlay was interpreted as potential areas of conflict where spatial inequity can be greatest because of the differential capabilities of users to access the same service-provisioning location. We base this assumption on Sikor and Nguyen (2007) who argued that greater capabilities to access ecosystem services indicate more extensive means to use them and derive higher benefits from them.

\section{Results}

\subsection{Intensity of use of ecosystem services over time}

In this study, service-provisioning hotspots represent areas of collective importance where ecosystem services (i.e. fish, timber and crops) are used more intensively than in other areas. We therefore consider these areas as locations of high-intensity use. Table 3 provides a summary of the amount of hotspots and their respective sizes for 1995 and 2015 in each of the study regions. Fig. 4 depicts the locations of service-provisioning hotspots for all three-ecosystem services. An expansion over time, from 1995 to 2015, for fish and timber provisioning hotspots can be observed, next to the development of road infrastructure and expansion of forestry concessions.

\subsubsection{Fish provision}

Table 3 shows that the percentage of increase in number and area of fish provisioning hotspots is larger in sub-region 1 than in sub-region 2 thus the intensity of use of this ecosystem services over time has been greater in the former.

\subsubsection{Timber provision}

The percentage of increase in the number of timber provisioning hotspots was slightly larger in sub-region 2 compared to sub-region 1 . However, the percentage of increase in the total area of timber-provisioning hotspots was almost five times larger in sub-region 1 than in sub-region 2. Based on these results, the overall intensification in use of timber provisioning hotspots was stronger in sub-region 1 than in subregion 2.

\subsubsection{Crop provision}

From the total area in crops derived from the 2000 forest cover map and comparing it with the total area mapped by the participants for the year 2015, we observed that the percentage of increase has doubled in sub-region 1 and tripled in sub-region 2 . Based on these results, the overall intensification in the use of crop provisioning areas was stronger in sub-region 2 than in sub-region 1. 
Table A5

Calculation of Gini Coefficient among clans for timber provision in 1995, sub-region 1.

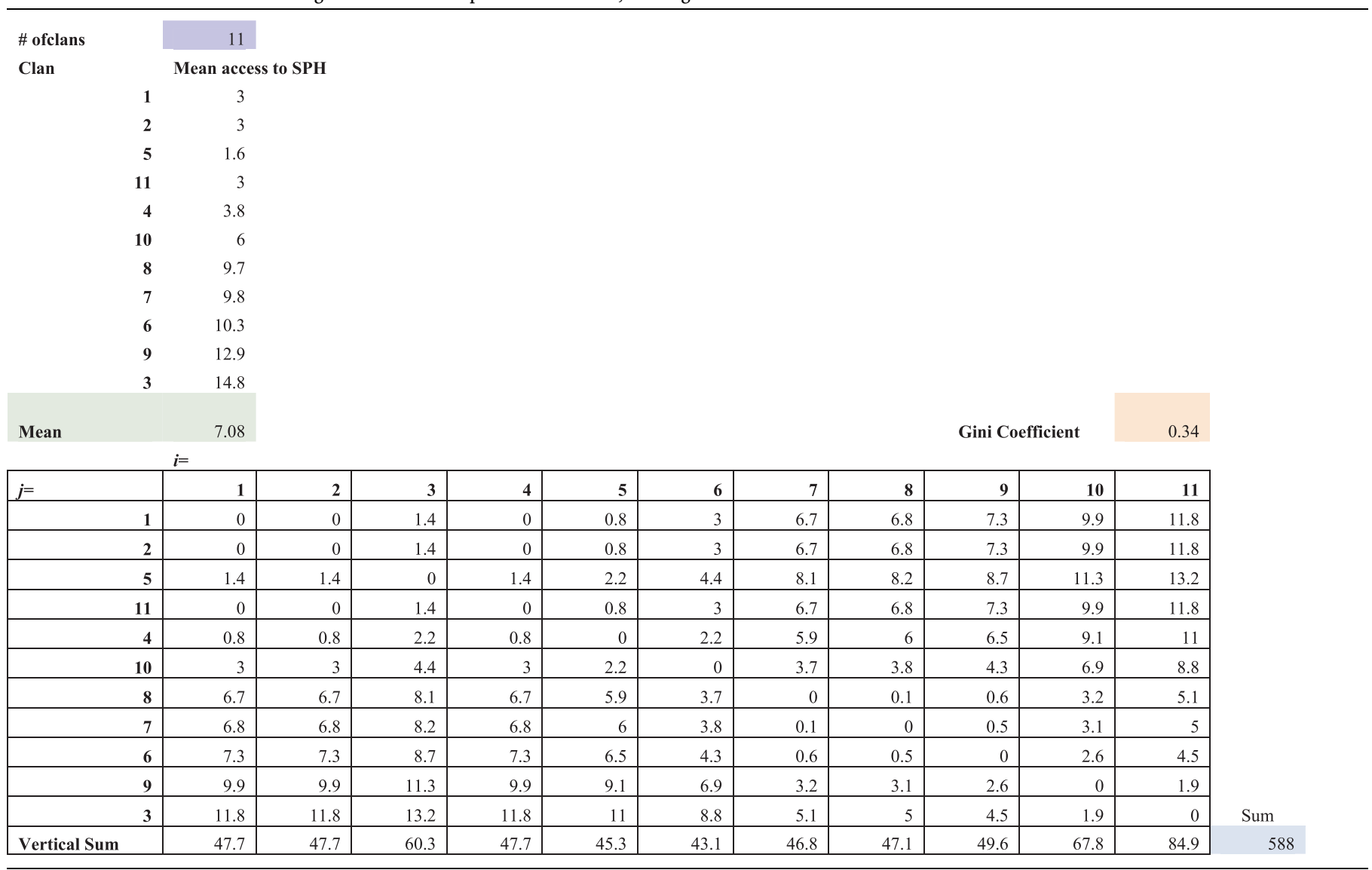

\subsection{Spatial equity according to clan membership}

The results in Tables 4 and 5 show the asymmetries in access capabilities of the different respondents for each clan in both sub-regions during the period analyzed.

\subsubsection{Fish provision}

The findings show the asymmetries in the capability of respondents belonging to each clan to access fish provisioning hotspots in both subregions. For example, Table 4 shows that respondents belonging to clan 6 in sub-region 1, represented by $1.3 \%$ of the total responses, appear to have higher capabilities of access to service-provisioning hotspots over time. The table also shows a three times increase in the access capabilities reported by the responses of the same clan in 1995. By contrast, respondents belonging to clan 5 , with $50.8 \%$ of the responses, was found to have low access capabilities to service-provisioning hotspots. Similarly, in sub-region 2 respondents belonging to clan 5, 6 and 13, represented by less than $4.8 \%$ of the total responses, showed to have large capabilities of access to fish provisioning hotspots. Interestingly, respondents belonging to clan 7 , with $1.6 \%$ of the total responses shows a remarkable increase in access capabilities to this ecosystem service over time. By contrast, respondents belonging to clan 1 in sub-region 2 , represented by $55.9 \%$ of the responses, appeared to have less access capabilities to fish provisioning hotspots over time (Table 5). Thus, these asymmetries in the capabilities of users show that there is spatial inequity among the clan respondents, in relation to fish provisioning hotspots in both sub-regions (we assume that spatial inequity occurs when the access capabilities of user groups is highly asymmetrical).

\subsubsection{Timber provision}

The analysis of access to timber provisioning hotspots shows that in sub-region 1, respondents belonging to clan 6 , represented by $1.3 \%$ of the responses, appeared to have one of the highest access capabilities to timber provisioning hotspots, while it shows that the access to hotspots locations reported by the respondents belonging to this clan doubled over time (Table 4). By contrast, respondents belonging to clan 5 , with $50.8 \%$ of the responses showed to have low access capabilities to timber provisioning hotspots over time. Likewise, in sub-region 2, respondents belonging to clan 5 , represented by $2.0 \%$ of the responses, had high access capabilities to timber provisioning hotspots in 2015 with this increasing over time. Contrastingly, respondents belonging to clan 1 in this sub-region, represented by $55.9 \%$ of the responses, was found to have low access capabilities to these hotspots over time (Table 5). Therefore, there is spatial inequity among the respondents in access to timber provisioning hotspots in both sub-regions.

\subsubsection{Crop provision}

Spatial inequity in access to crop provisioning hotspots were also reported. For example, respondents belonging to clan 8 in sub-region 1 , represented by $3.8 \%$ of the responses, reported to have high access capabilities while respondents belonging clan 5, with the largest representation in the response reported low access capabilities to these service-provisioning hotspots (Table 4). Similarly, in sub-region 2, respondents belonging to clan 13 , represented by $1.3 \%$ of the responses, presented high access capabilities whereas respondents belonging to clan 1 , with $55.8 \%$ of the responses perceived less access capability (Table 5). For crop provisioning hotspots there are no primary data preceding 2015 (see Section 2.3).

\subsection{Spatial equity between sub-regions}

The results of the Gini coefficient are presented in Table 6 . 
Table A6

Calculation of Gini Coefficient among clans for timber provision in 2015, sub-region 1.

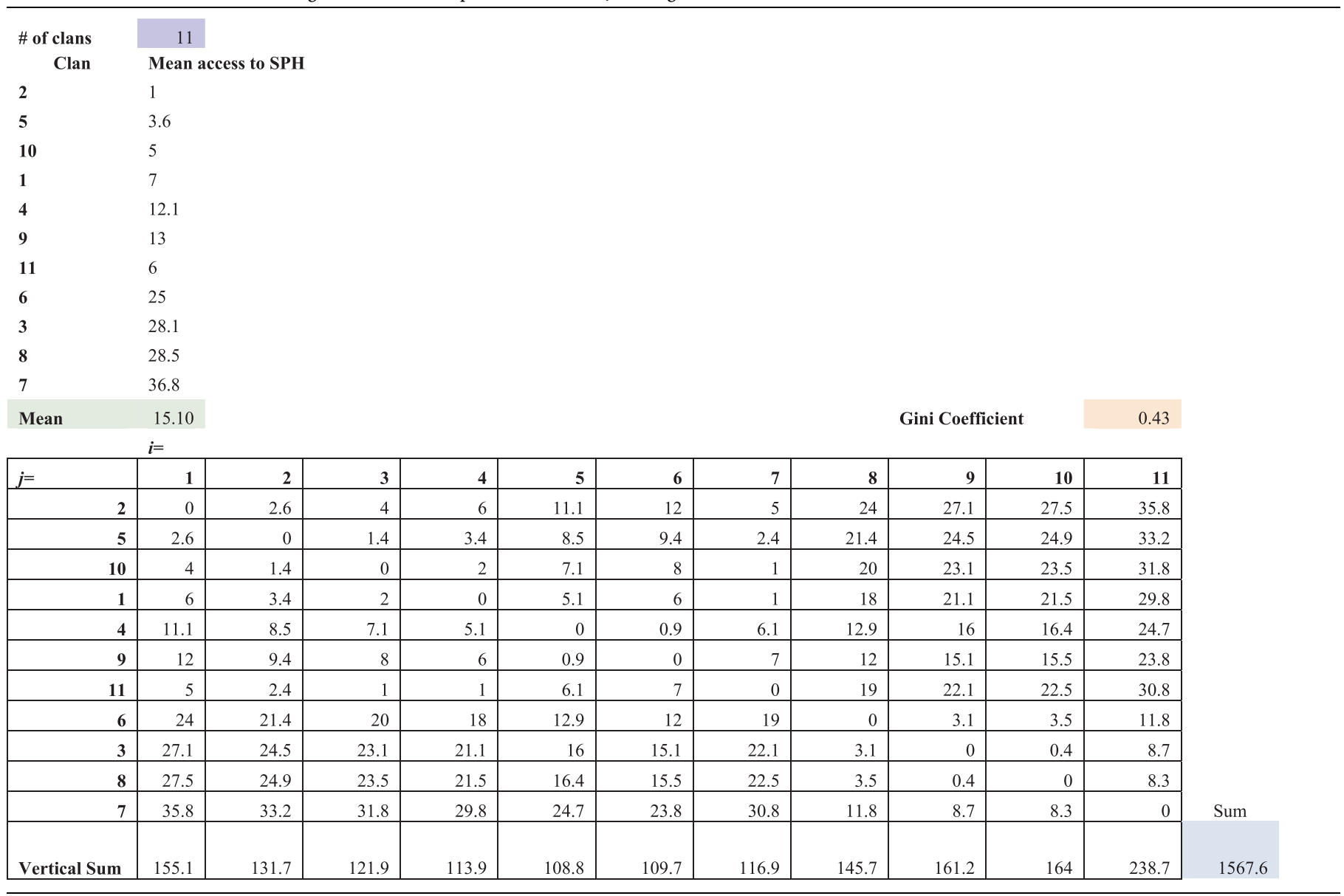

According to these values, spatial equity concerns regarding access to fish and timber provisioning hotspots did not exist in 1995 in sub-region 1, but emerged in 2015. Similarly, spatial equity concerns emerged for fish provision in sub-region 2, while equity concerns for timber provisioning pre-existed in 1995 and had decreased by 2015 .

\subsection{Spatial equity among users depending on their authority position}

The results on spatial equity across different levels of authority in each sub-region are presented in Fig. 5. A first overview of these graphs shows that the extent of the service-provisioning hotspots area claimed by each of the users in this category was on average 22 ha in sub-region 1 while in sub-region 2 this was 72 ha.

\subsubsection{Fish provision}

The analysis shows that in sub-region 1 , chiefs have the highest access capabilities to service-provisioning hotspots compared to the capabilities of regular community users. The data do not show substantial changes in access capabilities during the period analyzed. Similarly, in sub-region 2, the trend over time shows that members of the community with high-authority position such as chiefs and Dresimen hold the highest access capabilities to important fish provisioning locations over time. Thus, the asymmetries in access capabilities reported here show that there is spatial inequity in access to fish provisioning hotspots in both study cases, although this appeared to be larger in sub-region 2.

\subsubsection{Timber provision}

The analysis shows that chiefs have the highest access capabilities to access service-provisioning hotspots in both sub-regions. This asymmetry in access capabilities has become more pronounced over time for sub-region 2. By contrast, access capabilities of regular community members remained low in both sub-regions. Thus, there is spatial inequity in access to timber provisioning hotspots in both study cases, although this appeared to be larger in sub-region 2 .

\subsubsection{Crop provision}

Although an asymmetry in crop provisioning hotspots was present in sub-region 1, it was not as pronounced as in sub-region 2 where assistant chiefs and Dresimen appear to have the largest capabilities to access crops provisioning hotspots. For crop provisioning hotspots there are no primary data preceding 2015 (see section 2.3).

\subsection{Locations subject to conflicting claims}

Overlapping the access to service provisioning hotspots for different levels of authority and according to clan membership resulted in the identification of areas of potential conflict between ecosystem service users (see Fig. 4). These areas emerged in both regions over the period analyzed, however the amount and size of such conflict areas vary (Table 7). For example, fish provisioning hotspots subject to potential conflicting were more numerous and larger in sub-region 2. By contrast, in sub-region 1 the number of timber provisioning hotspots subject to potential conflicting was larger in 1995 (and had increased by a factor five in the period analyzed), whereas the extent of these areas was larger in sub-region 2 in the year 2015. For crop provisioning hotspots there are no primary data preceding 2015 (see Section 2.3). The results for 2015 show that crop provisioning hotspots subject to conflicting 
Table A7

Calculation of Gini Coefficient among clans for crops provision in 2015, sub-region 1.

\begin{tabular}{|c|c|c|c|c|c|c|c|c|c|c|c|c|}
\hline \# of clans & 11 & & & & & & & & & & & \\
\hline \multirow[t]{12}{*}{ Clan } & \multicolumn{12}{|c|}{ Mean access to SPH } \\
\hline & 8 & & & & & & & & & & & \\
\hline & 7.8 & & & & & & & & & & & \\
\hline & 10.3 & & & & & & & & & & & \\
\hline & 11.2 & & & & & & & & & & & \\
\hline & 1.8 & & & & & & & & & & & \\
\hline & 6.3 & & & & & & & & & & & \\
\hline & 5.7 & & & & & & & & & & & \\
\hline & 22.1 & & & & & & & & & & & \\
\hline & 4.3 & & & & & & & & & & & \\
\hline & 2.3 & & & & & & & & & & & \\
\hline & 16.2 & & & & & & & & & & & \\
\hline Mean & 8.73 & & & & & & & \multicolumn{3}{|c|}{ Gini Coefficient } & 0.36 & \\
\hline \multicolumn{12}{|c|}{$i=$} & \\
\hline$j=$ & 1 & 2 & 3 & 4 & 5 & 6 & 7 & 8 & 9 & 10 & 11 & \\
\hline 1 & 0 & 0.2 & 2.3 & 3.2 & 6.2 & 1.7 & 2.3 & 14.1 & 3.7 & 5.7 & 8.2 & \\
\hline 2 & 0.2 & 0 & 2.5 & 3.4 & 6 & 1.5 & 2.1 & 14.3 & 3.5 & 5.5 & 8.4 & \\
\hline 3 & 2.3 & 2.5 & 0 & 0.9 & 8.5 & 4 & 4.6 & 11.8 & 6 & 8 & 5.9 & \\
\hline 4 & 3.2 & 3.4 & 0.9 & 0 & 9.4 & 4.9 & 5.5 & 10.9 & 6.9 & 8.9 & 5 & \\
\hline 5 & 6.2 & 6 & 8.5 & 9.4 & 0 & 4.5 & 3.9 & 20.3 & 2.5 & 0.5 & 14.4 & \\
\hline 6 & 1.7 & 1.5 & 4 & 4.9 & 4.5 & 0 & 0.6 & 15.8 & 2 & 4 & 9.9 & \\
\hline 7 & 2.3 & 2.1 & 4.6 & 5.5 & 3.9 & 0.6 & 0 & 16.4 & 1.4 & 3.4 & 10.5 & \\
\hline 8 & 14.1 & 14.3 & 11.8 & 10.9 & 20.3 & 15.8 & 16.4 & 0 & 17.8 & 19.8 & 5.9 & \\
\hline 9 & 3.7 & 3.5 & 6 & 6.9 & 2.5 & 2 & 1.4 & 17.8 & 0 & 2 & 11.9 & \\
\hline 10 & 5.7 & 5.5 & 8 & 8.9 & 0.5 & 4 & 3.4 & 19.8 & 2 & 0 & 13.9 & \\
\hline 11 & 8.2 & 8.4 & 5.9 & 5 & 14.4 & 9.9 & 10.5 & 5.9 & 11.9 & 13.9 & 0 & \\
\hline Vertical Sum & 47.6 & 47.4 & 54.5 & 59 & 76.2 & 48.9 & 50.7 & 147.1 & 57.7 & 71.7 & 94 & 754.8 \\
\hline
\end{tabular}

claims were larger in sub-region 2.

\section{Discussion}

\subsection{Intensification of service-provisioning hotspots}

The consideration of the spatial configuration of access to ecosystem services, such as the extent and number of ecosystem service hotspots is important to express the intensity of ecosystem service provision (De Vreese et al., 2016). The results of this study have shown that the provision of fish and timber is more intense in sub-region 1, while the intensification of crop provision has been larger in sub-region 2 . The stronger intensity of crop provision in sub-region 2 is in line with the subsistence economy in this sub-region. Crops are mainly used for subsistence and the surplus, if any, is either sold or bartered to provide for other basic needs (Amazon Conservation Team, 2010).

Overall, the total sizes of service-provisioning hotspots are larger in sub-region 2 than in sub-region 1 for all studied ecosystem services. The large areas of service-provisioning hotspots in sub-region 2 can be related to population pressure, as this is the sub-region with the highest population size of the entire Upper Suriname River basin (Table 1). Local narratives have also suggested that Saramaka population from more remote places in the basin have been migrating to sub-region 2 in order to be closer to the economic and education opportunities offered by the pavement, in 2010, of a major road in sub-region 1 (the so-called Atjoni highway). It is possible that internal migrants do not settle in sub-region 1, which is closer to the road and to local markets than subregion 2 , because of a scarcity of land for shifting agriculture in that region (Fleskens and Jorritsma, 2010). Thus, an increase in inhabitants implies an increase in the local areas of use.
The larger intensification of fish provision in sub-region 1 shows a larger dependency on this ecosystem service. However, previous studies in this sub-region have shown that fishing grounds have been depleted and that Saramaka communities in this area are dependent on smaller fish with little nutritional value found in nearby the villages (RamirezGomez et al., 2017). Presumably, the intensification in the provision of fish in sub-region 1 is related to overexploitation and decrease of larger fishing grounds. Regarding the intensification in timber provision in sub-region 1 over time, we argue that it is probably related to the pavement of the Atjoni highway and the emergence of forestry concessions. For example, a report of the Forest Service shows an increase by $45 \%$ in the production of round wood in the area between 2010 and 2016 (Stichting voor Bosbeheer en Bostoezicht, 2016). Wood production may currently have further increased with the completion, in 2017, of $48 \mathrm{~km}$ of road running from the Atjoni highway deep into the forest (the so-called Pusugrunu road). Forestry concessions are not yet developed in sub-region 2, but these are planned. Traditionally, in this sub-region, timber is locally used on a small scale for the construction of houses, boats and crafts. However, a request for timber exploitation of 92,200 ha of forest has been made to the official authority by local community members (Stichting voor Bosbeheer en Bostoezicht, 2019). These facts give us reasons to believe that the actual intensification in the provision of timber in sub-region 2 is expected to be delayed until roads expand into the area. Such intensification could become stronger in sub-region 2 than actually is the case in sub-region 1 , because of the higher population density in the former and the larger extension of the area requested for timber extraction. 
Table A8

Calculation of Gini Coefficient among clans for fish provision in 1995, sub-region 2.

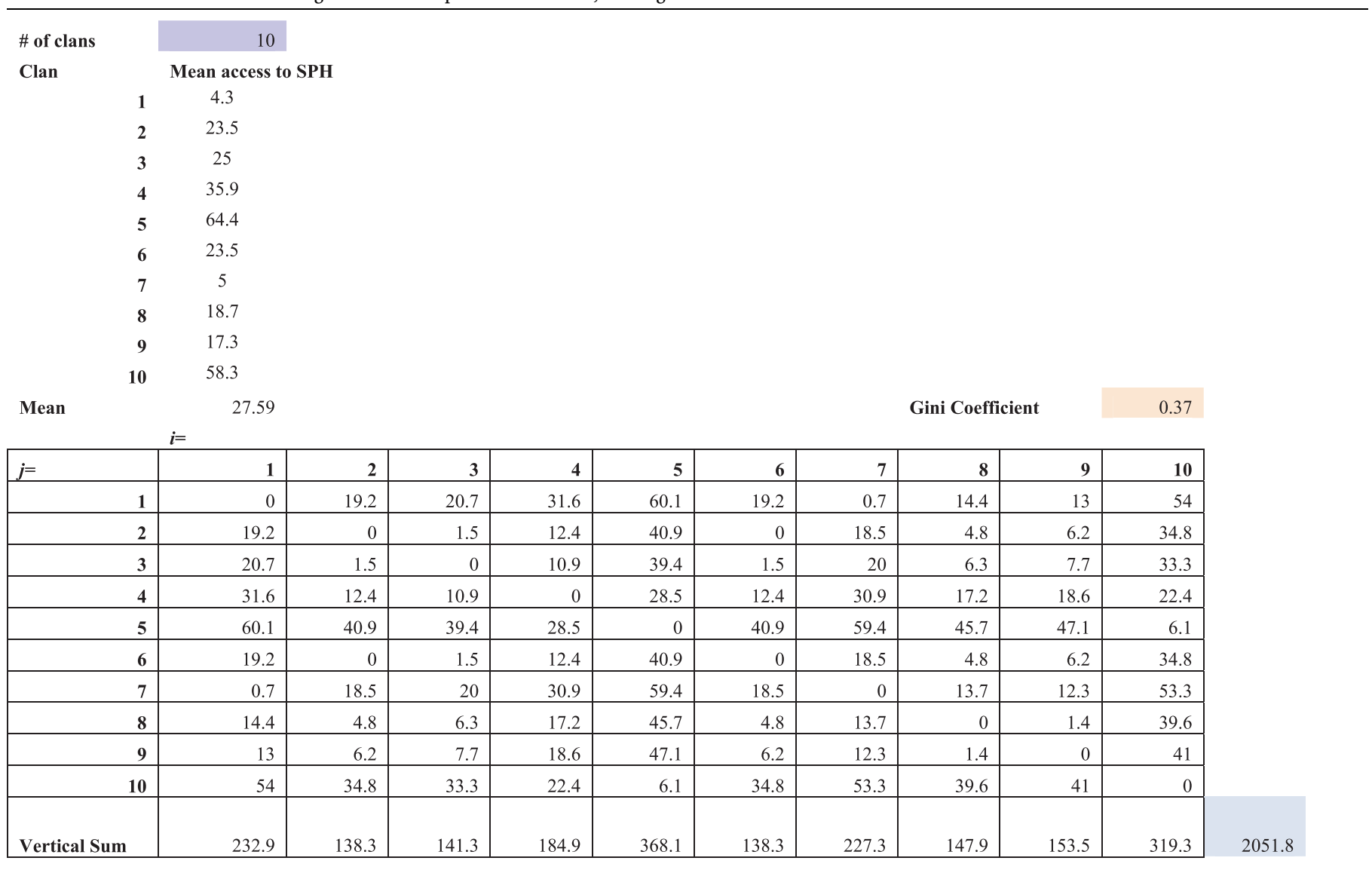

\subsection{Spatial equity among clans and between sub-regions}

Based on the representation of each clan in the responses, the findings in this study show that there is spatial inequity in access to service provisioning hotspots for all ecosystem services among clan respondents. Arguably, this finding may be related to pre-established ethnic hierarchies mediating de facto harvesting rights of forest areas among the Saramaka communities (Price, 1975). This conclusion is supported by findings in Torpey-Saboe et al., (2015), who showed that inequity in benefit sharing from forestry activities among castes in Nepal is mainly determined by underlying social disparities associated with ethnic cleavages within communities. However, this explanation is more relevant for timber provisioning services, as forest is the only resource in the area where clan hierarchies may apply. Therefore, the large asymmetry in the access capabilities reported by respondents belonging to clan 7, to fish provisioning hotspots might need more data and deeper analysis. Thus, given the differential access capabilities to ecosystem services that we found within clan responses, an important conclusion derived from this study is that the factors affecting access to service-provisioning hotspots by this user group is certainly complex and hence, analysis that is more comprehensive would be needed to better support the conclusions.

No major differences were found in the spatial equity patterns among sub-regions. Yet, our findings around the Gini coefficient show that inequity in access to service-provisioning hotspots emerged for fish and timber in sub-region 1, while it has increased for fish in sub-region 2. An inspection of the land use information in Fig. 2, suggests that the emergence of spatial inequity in sub-region 1 by 2015 coincides with the emergence of roads and forestry concessions. This can be expected as these developments may increase the value of ecosystem services that are subject to local elite capture as noted by Iversen et al. (2006).
Our data provide some evidence for some of the ecosystem services. For example, in relation to the inequity found in access to timber provisioning hotspots in sub-region 1 , the findings in Table 4 show that clan 3 and 6, which are influential clans (Price, 1975), experienced, respectively, a two and three-fold increase in their access to timber provisioning hotspots during the period analyzed. By contrast, the increase in the Gini coefficient for fish and crops in sub-region 2 is likely related to population growth because of internal migration of community members belonging to the same clans. Such migration has been triggered by the expectations created by the foreseeable expansion of economic land use developments in this sub-region (Stichting voor Bosbeheer en Bostoezicht, 2019) as was also indicated during the focus groups discussions. With newcomers, competition for provisioning ecosystem services can increase as noted by Ramirez-Gomez et al. (2015) in the Colombian Amazon. Contrastingly, the Gini Coefficient for timber provision in sub-region 2 decreased during the period analyzed, although it remained high over time. Arguably, this decrease might be only temporary until the 92,000 hectares of forest requested for commercial forestry activities are granted to the local communities in the area. Deriving from these conclusions, we suggest that pre-existing spatial inequity found in sub-region 2 may be exacerbated as soon as economic opportunities get within reach.

\subsection{Spatial equity assessment across authority position}

The asymmetries reported in this study showed that those with a high authority position have been able to maintain access to fish provisioning hotspots while regular community members have not. From our findings and drawing on the copious literature linking access to livelihoods with capabilities and capitals (Bebbington, 1999; Chambers and Conway, 1992; Haan and Zoomers, 2005; Lienert and Burger, 
Table A9

Calculation of Gini Coefficient among clans for fish provision in 2015, sub-region 2.

\begin{tabular}{lrc} 
\# of clans & & \multicolumn{2}{c}{10} \\
Clan & & Mean access to SPH \\
& $\mathbf{1}$ & 2.9 \\
$\mathbf{2}$ & 8.6 \\
$\mathbf{3}$ & 14 \\
$\mathbf{4}$ & 80.4 \\
$\mathbf{5}$ & 50.8 \\
$\mathbf{6}$ & 27.5 \\
$\mathbf{7}$ & 97 \\
$\mathbf{8}$ & 29.9 \\
$\mathbf{9}$ & 14.3 \\
$\mathbf{1 0}$ & 117.6
\end{tabular}

Mean 44.3

Gini Coefficient

0.47

\begin{tabular}{|c|c|c|c|c|c|c|c|c|c|c|c|}
\hline$j=$ & 1 & 2 & 3 & 4 & 5 & 6 & 7 & 8 & 9 & 10 & \\
\hline 1 & 0 & 5.7 & 11.1 & 77.5 & 47.9 & 24.6 & 94.1 & 27 & 11.4 & 114.7 & \\
\hline 2 & 5.7 & 0 & 5.4 & 71.8 & 42.2 & 18.9 & 88.4 & 21.3 & 5.7 & 109 & \\
\hline 3 & 11.1 & 5.4 & 0 & 66.4 & 36.8 & 13.5 & 83 & 15.9 & 0.3 & 103.6 & \\
\hline 4 & 77.5 & 71.8 & 66.4 & 0 & 29.6 & 52.9 & 16.6 & 50.5 & 66.1 & 37.2 & \\
\hline 5 & 47.9 & 42.2 & 36.8 & 29.6 & 0 & 23.3 & 46.2 & 20.9 & 36.5 & 66.8 & \\
\hline 6 & 24.6 & 18.9 & 13.5 & 52.9 & 23.3 & 0 & 69.5 & 2.4 & 13.2 & 90.1 & \\
\hline 7 & 94.1 & 88.4 & 83 & 16.6 & 46.2 & 69.5 & 0 & 67.1 & 82.7 & 20.6 & \\
\hline 8 & 27 & 21.3 & 15.9 & 50.5 & 20.9 & 2.4 & 67.1 & 0 & 15.6 & 87.7 & \\
\hline 9 & 11.4 & 5.7 & 0.3 & 66.1 & 36.5 & 13.2 & 82.7 & 15.6 & 0 & 103.3 & \\
\hline 10 & 114.7 & 109 & 103.6 & 37.2 & 66.8 & 90.1 & 20.6 & 87.7 & 103.3 & 0 & \\
\hline Vertical Sum & 414 & 368.4 & 336 & 468.6 & 350.2 & 308.4 & 568.2 & 308.4 & 334.8 & 733 & 4190 \\
\hline
\end{tabular}

2015), it appears that the spatial inequity reported in this study for this user group may be related to power, influence and the financial resources that user groups have. In fact, local traditional authorities in the region receive a monthly wage and enjoy benefits for working with the government. Furthermore, the spatial inequity found in the access of chiefs and assistant chiefs to timber provisioning hotspots were to be expected. Customary laws enable these authorities to manage and exploit community forests on behalf of the community (Amazon Conservation Team (ACT), 2010), and to formally apply for logging permits. Currently such permits have been granted only in sub-region 1 and several applications for logging permits are being processed for sub-region 2. Our findings have shown that access of chiefs to timber provisioning hotspots doubled in sub-region 1 as shown in Fig. 5. It was reported during focus groups discussions that since logging permits have been granted to local traditional authorities in sub-region 1, there are big concerns regarding the distribution of benefits derived from logging on lands that have the status of community forests. It has created windows of opportunity for local authorities to increase their power and to exert a significant influence and control over important forest areas. Hence, these findings demonstrate that pressures actually exacerbate the influence of some elites within the community. This is in line with Sikor and Lund (2009), who argued that access and property regarding ecosystem services are intimately associated with the exercise of power and authority, which is in turn influenced by large political economic forces.

\subsection{Areas subject to potential conflicts}

In this study, areas with potential conflict were driven by the spatial overlap between users reporting high access to service-provisioning hotspots and users whose access to these important locations was perceived low (Tables 4 and 5). Thus, the mapping process reported herein explicitly visualizes the places where conflict between users having disproportionate access to ecosystem service-provisioning hotspots is most likely. It also shows the influence of external pressures in underpinning conflicted space. For example, the larger areas of potential conflict concerned access to timber hotspots in both study regions. Their intensification in sub-region 1 coincides mainly with the improvement of roads and the appearance of commercial forestry. In subregion 2, we found that the largest timber provisioning hotspots had more than three quarters of its area under potential conflict. The increasing population in this region and the proximity of these hotspots to the human settlement give us reasons to believe that conflict locations are underpinned by demographic pressure. Other studies across tropical forest found similar conflicts associated to access to timber ecosystem services (e.g. Pacheco et al., 2010; Dasgupta and Beard, 2007; Iversen et al., 2006). However, without explicitly identifying areas of potential conflict, some spatial inequity between ecosystem service users might remain invisible. For example, some areas of potential conflict identified for fish and timber provision were remote from settlements (see Fig. 4). This means that forests areas should not be assumed be free from conflict in virtue of their remoteness. Mediating potential conflicts is an important aim at both local and higher land use planning scales, and findings of differential access capabilities such as those reported here underscore the need to integrate and account for spatial equity in the planning of commercial logging activities.

Lastly, the identification and mapping of areas subject to potential conflict between ecosystem service users represent locations where one of the user may have limited access to ecosystem service hotspots and therefore in these areas, spatial equity can be expected to be greatest. 
Table A10

Calculation of Gini Coefficient among clans for timber provision in 1995, sub-region 2.

$\begin{array}{lcc}\begin{array}{l}\text { \# of clans } \\ \text { Clan }\end{array} & & \\ & & \text { Mean access } \\ & \mathbf{1} & 3.2 \\ & \mathbf{7} & 5 \\ & \mathbf{2} & 7.8 \\ \mathbf{6} & 8.25 \\ \mathbf{3} & 18.6 \\ \mathbf{9} & 25.3 \\ \mathbf{5} & 28 \\ \mathbf{8} & 29.8 \\ \mathbf{4} & 63.25 \\ \mathbf{1 0} & 80.3\end{array}$

Mean 26.95

10

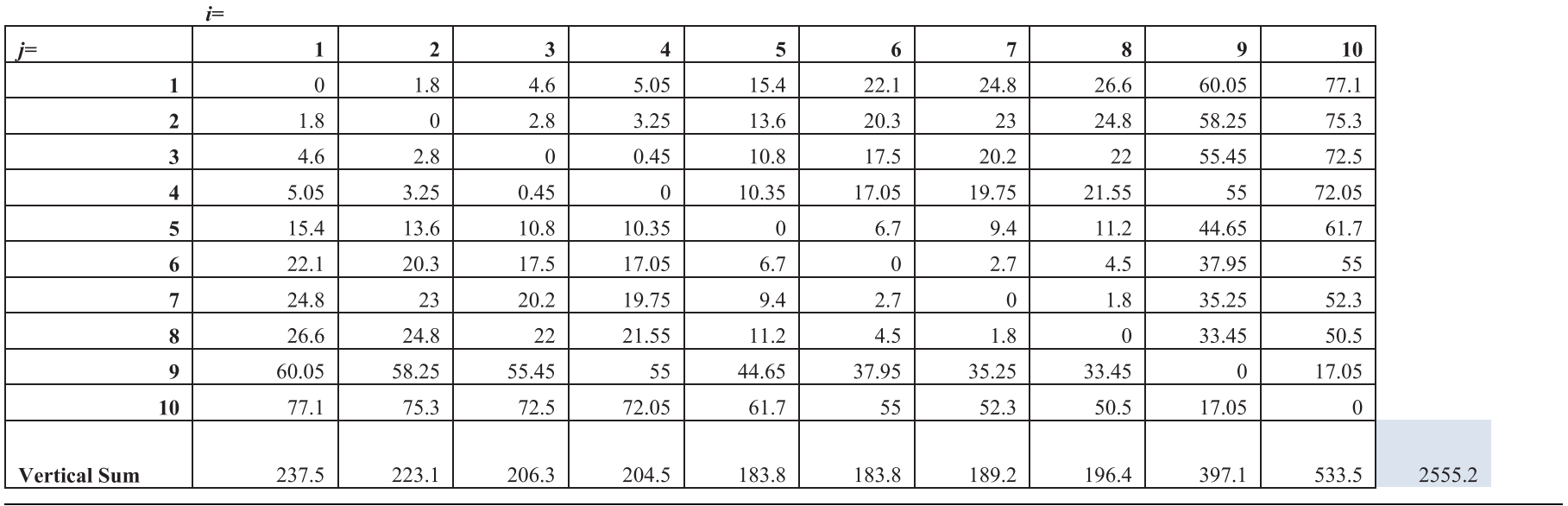

The use of participatory mapping methodology was an effective means for assessing potential conflict areas in a region characterized by data scarcity. Hence, it provided a method for the inclusion and consideration of asymmetries in the use of space by different ecosystem services users, by means of relatively little data and straightforward analysis. Although the use of participatory mapping does not bring solutions regarding potential conflicts, the delineation of these locations provides land use planning practitioners (for the case of conflict around commercial forestry activities) with a substantive basis for a discussion of future land use and can inform early conflict management strategies. Similarly, local communities could use this information in an internal dialogue about equity in access to important ecosystem service locations.

\subsection{What factors were found to influence spatial equity the most?}

In synthesis, this study found two main factors affecting spatial equity the most: social structure and external pressures including population pressure and land use pressures from road infrastructure and commercial forestry activities (Fig. 6). These factors are interrelated because land use changes such roads and expansion of commercial activities increase the influx of local inhabitants to these regions who come to be closer to economic opportunities that these developments bring. In turn, with influx of population the complexity of clan and intra-clan relationship determining de facto access rights to ecosystem service locations is exacerbated. As Torpey-Saboe et al. (2015) argued, a high ethnic heterogeneity within traditional communities may constraints the likelihood of equity outcomes as there can be more competition within ethnic groups to gain access to power and control, hence, cooperative outcomes may be more difficult to obtain.
Moreover, similar studies have also found positive correlation between equity in access to ES and social structure. For example, Ward et al. (2018) found that local laws, customs and social identity were key factors mediating access to forest resources among local communities in Madagascar. Oli et al. (2016) found that influential actors such as village elites, local chiefs, and village elders in Western Nepal, tend to align access to community forestry benefits to their interest. Finally, Agarwala and Ginsberg (2017) found that external pressure such population increase and markets affect equity in outcomes from community based management. Although these authors have come to similar findings, their analysis focuses on either internal (social structure) or external (population pressure and markets) factors while our study analyses these in an integral way. Also, the spatio-temporal relationship of these factors addressed in the present work, makes their understanding simpler by local people and decision makers, which increases the likelihood of consideration in decision-making. This is important because the management of ecosystems is increasingly incorporating the relevance of place which has been a long-standing issue in social science (McLain et al., 2013).

\subsection{Caveats}

We acknowledge a number of caveats in the implementation of the present study. First, we add a note of methodological caution regarding our temporal analysis. Since the 1995 datasets were based on perception, it relied on the memory of the respondents, which affects the spatial accuracy of our findings. The effect of bias in our data was partly redressed by using a threshold to define consistent spatial aggregations of service-provisioning locations based on 492 responses, both for 1995 and 2015, similar to the hotspot approach used in Brown and Pullar 
Table A11

Calculation of Gini Coefficient among clans for timber provision in 2015, sub-region 2.

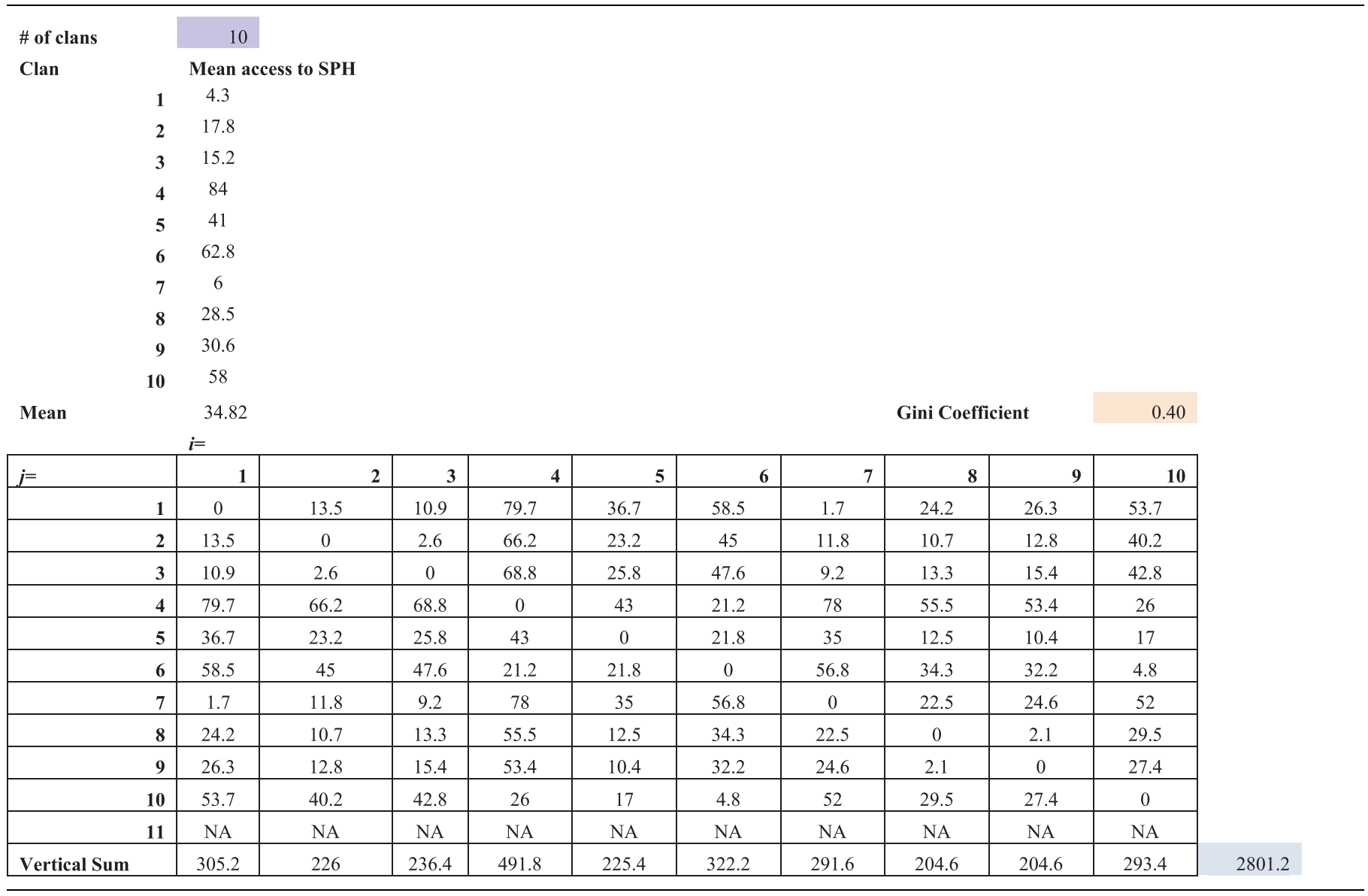

(2012) and Ramirez-Gomez et al. (2013). Moreover, our analysis over time was done according to two snapshots in time (1995 and 2015) which could limit our understanding of the facts influencing service provision and ultimately spatial equity. For example, during focus groups discussion, participants indicated that precious wood was removed from sub-region 1 (Eastern side) towards the end of the 90 's beginning of the $00^{\prime}$ by Chinese and Malaysia logging companies. This means that by 2015 , the availability of timber provisioning was diminished in sub-region 1, which could explain why spatial inequity indicators for timber had lower values in this sub-region, compared to sub-region 2 where timber resources have historically been more abundant. Therefore, we suggest that the temporal patterns of equity for this ecosystem service should be analyzed in a shorter period than the 20 years period used in this study. Furthermore, participants suggested during focus groups discussions that some people from the area had become wealthy and migrated to Paramaribo. Therefore, part of the process of elite capture is probably not visible in the two snapshots. Related to this, we suggest including people who out-migrated to cities in the group of respondents in future research. Similarly, earned rights of use from matrilineal birthrights, patrilineal kinship relations and from traditional marriage are aspects underpinning competition for ecosystem services in the study region (Amazon Conservation Team, 2010). Yet, this was not reflected in our data. Therefore, we suggest the need for further research on ethnic hierarchies ruling access to ecosystem services in traditional communities to support our conclusions regarding delineation of conflict locations.

\section{Conclusion}

Equity is an important element in the implementation of policies related to ecosystem services. However, equity aspects and complex human interactions in the use of space are often overlooked in land use policy processes, in particular in data scarce and remote tropical forest regions where traditional communities are living and external pressures are expanding into tropical forests regions. These processes can have important implications for equity in access to ecosystem services, which emphasizes the importance of a rapid, but also robust way to operationalize the study of spatial equity issues in these data-scarce environments. This study proposes a participatory mapping methodology that uses relatively little data and straightforward analysis, to unveil spatial equity issues that might be otherwise hidden. In this way, important gaps in knowledge regarding spatio-temporal patterns of equity can be filled in core areas of tropical forest regions characterized by data scarcity. This is important because in these regions, the absence of trustworthy and robust data have obscured equity aspects in ecosystem service provision, as there is no information against which to measure the influence that social and land use factors can have in this.

The spatial equity analysis implemented in this study revealed asymmetries in access to ecosystem services hotspots for fish, timber and crops based on clan membership and authority position of community members. Spatial equity concerns already existed in the most remote sub-region in this study, which was affected to a much lesser extent by land use pressures. However, roads, logging and mining activities were likely to have exacerbated some of these asymmetries in the more remote sub-region (sub-region 2). Although the use of participatory mapping does not bring solutions regarding the spatial inequity found, it facilitated its assessment and a deeper understanding of the complexity of relationships between ecosystem service users in space, as well as the role of external pressures in underpinning spatial inequity in a data scarcity context. This is an important starting point 
Table A12

Calculation of Gini Coefficient among clans for crops provision in 2015, sub-region 2.

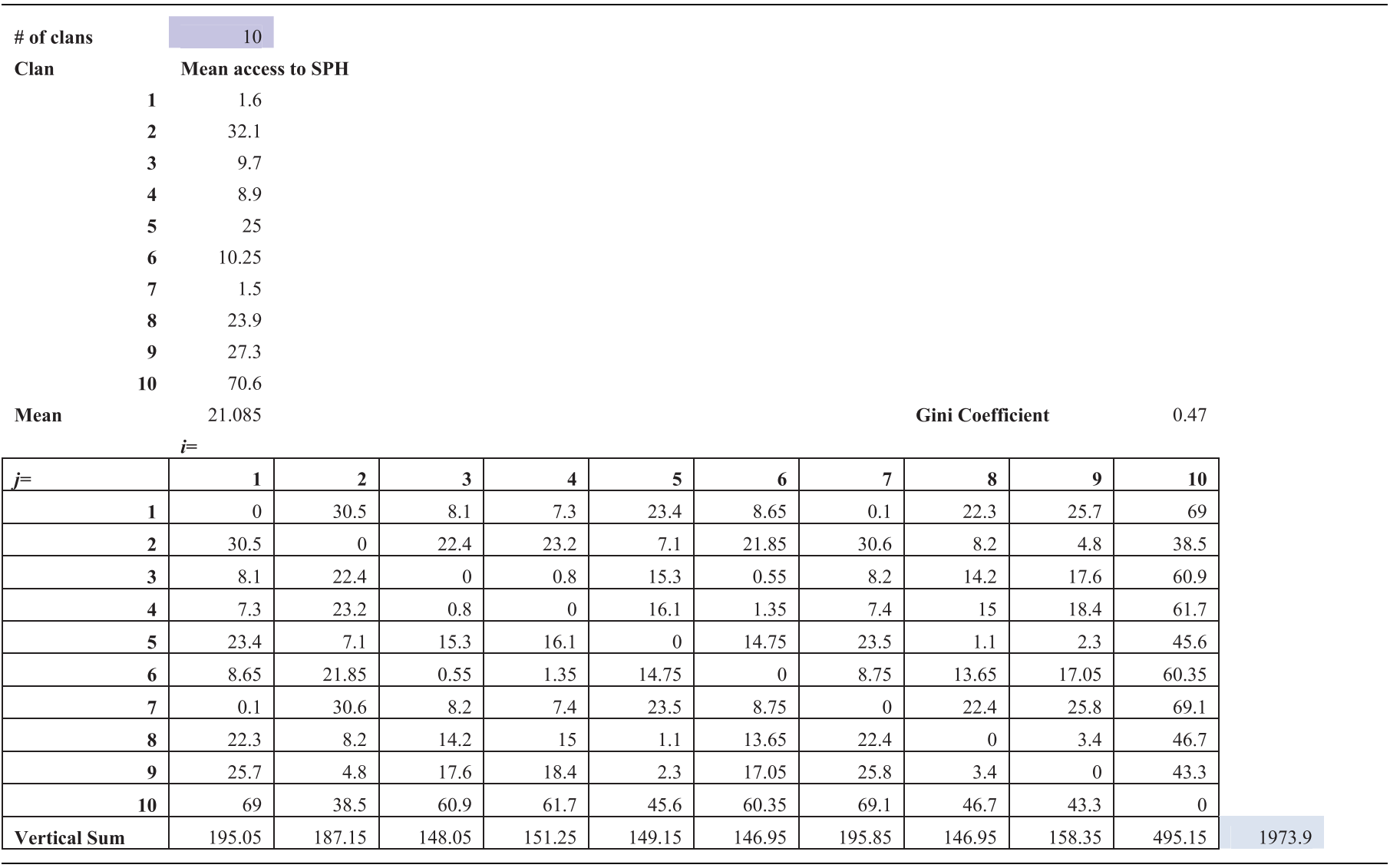

for the potential users of this information, namely NGOs and land use planners, who in the absence of detailed information, may tend to see local communities within a landscape as a homogeneous group. Therefore, this knowledge cautions external actors not to generalize nor to apply blueprints in their development projects, to the access that local communities in the landscape exercise to service-provisioning hotspots. Considering these differences could avoid mismatches between top-down and bottom up social and political processes, underlining the importance to make these visible in a relative short time. Lastly, the resulting spatial equity patterns and indicators in this study, can be used to support a proactive land use planning process guided by principles of participation, recognition of local concerns, and equity regarding access to ecosystem services provisioning hotspots. The challenge is to further explore the utility of this methodological approach to spatial equity assessments for other social contexts across tropical forest regions. Yet, its application in this study demonstrates how participatory mapping can link science to practice: by functioning as a scientific field that brings different assessment approaches together, and by contributing to sound and equitable management of tropical forests.

\section{Declaration of Competing Interest}

The authors declare that they have no known competing financial interests or personal relationships that could have appeared to influence the work reported in

this paper

\section{Acknowledgments}

The authors are grateful to all members of the local communities of Pikin Slee and Kajapaati who participated in this study. We thank Nalini Mahesh and Rawella Dahl for their contribution to data collection. We acknowledge the work of the foundation Wan Mama Pikin related to logistics and coordination of interviews. This study was part of a project of Tropenbos International Suriname (Project 13103 LUP) within the Productive Landscapes Program. Financial support came from the UNDP-GEF-Small Grant Program (Project SUR/SGP/OP5/Y4/ CORE/BD/15/47). We are grateful to Rudi van Kanten from Tropenbos International Suriname, for his continuous feedback relevant to the local context. We also thank Jacobus De Ridder for carefully reading this manuscript and providing useful insights and guidance. Ton Markus prepared the layout of Figs. 1, 2, 4 and 5.

\section{Appendix A}




\section{References}

Agarwala, M., Ginsberg, J.R., 2017. Untangling outcomes of de jure and de facto community-based management of natural resources. Conserv. Biol. 31, 1232-1246. https://doi.org/10.1111/cobi.12954.

Amazon Conservation Team (ACT), 2010. Land rights, tenure and use of indigenous peoples and maroons in Suriname. Amazon Conservation Team, Suriname.

Anderson, J., Mehta, S., Epelu, E., Cohen, B., 2015. Managing leftovers: does community forestry increase secure and equitable access to valuable resources for the rural poor? In: For. Policy Econ., The politics of community forestry in a Global Age - A critical analysis, pp. 47-55. https://doi.org/10.1016/j.forpol.2014.12.004.

Barnaud, C., Van Paassen, A., 2013. Equity, power games, and legitimacy: dilemmas of participatory natural resource management. Ecol. Soc. 18. https://doi.org/10.5751/ ES-05459-18022.1.

Bebbington, A., 1999. Capitals and capabilities: a framework for analyzing peasant viability, rural livelihoods and poverty. World Dev. 27, 2021-2044. https://doi.org/10. 1016/S0305-750X(99)00104-7.

Bennett, E.M., Chaplin-Kramer, R., 2016. Science for the sustainable use of ecosystem services. F1000Research 5. https://doi.org/10.12688/f1000research.9470.1.

Bennett, E.M., Cramer, W., Begossi, A., Cundill, G., Díaz, S., Egoh, B.N., Geijzendorffer, I.R., Krug, C.B., Lavorel, S., Lazos, E., Lebel, L., Martín-López, B., Meyfroidt, P., Mooney, H.A., Nel, J.L., Pascual, U., Payet, K., Harguindeguy, N.P., Peterson, G.D., Prieur-Richard, A.-H., Reyers, B., Roebeling, P., Seppelt, R., Solan, M., Tschakert, P., Tscharntke, T., Turner II, B., Verburg, P.H., Viglizzo, E.F., White, P.C., Woodward, G., 2015. Linking biodiversity, ecosystem services, and human well-being: three challenges for designing research for sustainability. Curr. Opin. Environ. Sustainable Open Issue 14, 76-85. https://doi.org/10.1016/j.cosust.2015.03.007.

Birkhofer, K., Diehl, E., Andersson, J., Ekroos, J., Früh-Müller, A., Machnikowski, F., Mader, V.L., Nilsson, L., Sasaki, K., Rundlöf, M., Wolters, V., Smith, H.G., 2015. Ecosystem services-current challenges and opportunities for ecological research. Front. Ecol. Evol. 2. https://doi.org/10.3389/fevo.2014.00087.

Bocci, C., Fortmann, L., Sohngen, B., Milian, B., 2018. The impact of community forest concessions on income: an analysis of communities in the Maya Biosphere Reserve. World Dev. 107, 10-21. https://doi.org/10.1016/j.worlddev.2018.02.011.

Brown, G.G., Pullar, D.V., 2012. An evaluation of the use of points versus polygons in public participation geographic information systems using quasi-experimental design and Monte Carlo simulation. Int. J. Geogr. Inf. Sci. 26, 231-246. https://doi.org/10. 1080/1 3658816.2011.585139.

Brown, K., Corbera, E., 2003. Exploring equity and sustainable development in the new carbon economy. Clim. Policy 3, S41-S56. https://doi.org/10.1016/j.clipol.2003.10. 004.

Centraal Bureau voor Burgerzaken (CBB), 2019. Data ressort Boven-Suriname over het jaar 2010 tot 2019 (Excel file). Paramaribo.

Chambers, R., Conway, G., 1992. Sustainable Rural Livelihoods: Practical Concepts for the 21st Century. Institute of Development Studies (UK).

Dasgupta, A., Beard, V.A., 2007. Community driven development, collective action and elite capture in Indonesia. Dev. Change 38, 229-249. https://doi.org/10.1111/j 1467-7660.2007.00410.x.

de Groot, R.S., Alkemade, R., Braat, L., Hein, L., Willemen, L., 2010. Challenges in integrating the concept of ecosystem services and values in landscape planning, management and decision making. In: Ecol. Complex., Ecosystem Services - Bridging Ecology Economy and Social Sciences, pp. 260-272. https://doi.org/10.1016/j. ecocom.2009.10.006.

De Vreese, R., Leys, M., Fontaine, C.M., Dendoncker, N., 2016. Social mapping of perceived ecosystem services supply - The role of social landscape metrics and social hotspots for integrated ecosystem services assessment, landscape planning and management. Ecol. Ind. 66, 517-533. https://doi.org/10.1016/j.ecolind.2016.01. 048.

Druckman, A., Jackson, T., 2008. Measuring resource inequalities: the concepts and methodology for an area-based Gini coefficient. Ecol. Econ. 65, 242-252. https://doi. org/10.1016/j.ecolecon.2007.12.013.

Felipe-Lucia, M.R., Martín-López, B., Lavorel, S., Berraquero-Díaz, L., Escalera-Reyes, J., Comín, F.A., 2015. Ecosystem services flows: why stakeholders' power relationships matter. PLoS ONE 10, e0132232. https://doi.org/10.1371/journal.pone. 0132232.

Fisher, B., Turner, R.K., Morling, P., 2009. Defining and classifying ecosystem services for decision making. Ecol. Econ. 68, 643-653. https://doi.org/10.1016/j.ecolecon. 2008.09.014.

Fisher, J.A., Patenaude, G., Giri, K., Lewis, K., Meir, P., Pinho, P., Rounsevell, M.D.A., Williams, M., 2014. Understanding the relationships between ecosystem services and poverty alleviation: a conceptual framework. Ecosyst. Serv. 7, 34-45. https://doi. org/10.1016/j.ecoser.2013.08.002.

Fisher, J.A., Patenaude, G., Meir, P., Nightingale, A.J., Rounsevell, M.D.A., Williams, M., Woodhouse, I.H., 2013. Strengthening conceptual foundations: analysing frameworks for ecosystem services and poverty alleviation research. Glob. Environ. Change 23, 1098-1111. https://doi.org/10.1016/j.gloenvcha.2013.04.002.

Fleskens, L., Jorritsma, F., 2010. A behavioral change perspective of maroon soil fertility management in traditional shifting cultivation in suriname. Hum. Ecol. 38, 217-236. https://doi.org/10.1007/s10745-010-9307-5.

Haan, L.D., Zoomers, A., 2005. Exploring the Frontier of livelihoods research. Dev. Change 36, 27-47. https://doi.org/10.1111/j.0012-155X.2005.00401.x.

Ifejika Speranza, C., Wiesmann, U., Rist, S., 2014. An indicator framework for assessing livelihood resilience in the context of social-ecological dynamics. Glob. Environ. Change 28, 109-119. https://doi.org/10.1016/j.gloenvcha.2014.06.005.

Iversen, V., Chhetry, B., Francis, P., Gurung, M., Kafle, G., Pain, A., Seeley, J., 2006. High value forests, hidden economies and elite capture: evidence from forest user groups in
Nepal's Terai. Ecol. Econ. 58, 93-107. https://doi.org/10.1016/j.ecolecon.2005.05. 021.

Jin, J., Wang, J., Ma, X., Wang, Y., Li, R., 2015. Equality of medical health resource allocation in China based on the Gini coefficient method. Iran. J. Publ. Health 44, 445-457.

Lakerveld, R.P., Lele, S., Crane, T.A., Fortuin, K.P.J., Springate-Baginski, O., 2015. The social distribution of provisioning forest ecosystem services: evidence and insights from Odisha, India. Ecosyst. Serv. 14, 56-66. https://doi.org/10.1016/j.ecoser.2015. 04.001.

Leach, M., Mearns, R., Scoones, I., 1999. Environmental entitlements: dynamics and institutions in community-based natural resource management. World Dev. 27, 225-247. https://doi.org/10.1016/S0305-750X(98)00141-7.

Lienert, J., Burger, P., 2015. Ecology and society: merging capabilities and livelihoods: analyzing the use of biological resources to improve well-being. Ecol. Soc. 20 https://doi.org/10.5751/ES-07405-200220.

McLain, R., Poe, M., Biedenweg, K., Cerveny, L., Besser, D., Blahna, D., 2013. Making sense of human ecology mapping: an overview of approaches to integrating sociospatial data into environmental planning. Hum. Ecol. 41, 651-665. https://doi.org/ 10.1007/s10745-013-9573-0.

Newing, H., Eagle, C.M., Puri, R.K., 2010. Conducting Research in Conservation: Social Science Methods and Practice. Routledge, New York.

Oli, B.N., Treue, T., Smith-Hall, C., 2016. The relative importance of community forests, government forests, and private forests for household-level incomes in the Middle Hills of Nepal. For. Policy Econ. 70, 155-163. https://doi.org/10.1016/j.forpol.2016 06.026 .

Pacheco, P., de Jong, W., Johnson, J., 2010. The evolution of the timber sector in lowland Bolivia: examining the influence of three disparate policy approaches. For. Policy Econ. 12, 271-276. https://doi.org/10.1016/j.forpol.2009.12.002.

Palomo, I., Martín-López, B., Potschin, M., Haines-Young, R., Montes, C., 2013. National Parks, buffer zones and surrounding lands: mapping ecosystem service flows. Ecosyst. Serv. 4, 104-116. https://doi.org/10.1016/j.ecoser.2012.09.001.

Palomo, I., Willemen, L., Drakou, E., Burkhard, B., Crossman, N., Bellamy, C., Burkhard, K., Campagne, C.S., Dangol, A., Franke, J., Kulczyk, S., Clec'h, S.L., Malak, D.A., Muñoz, L., Narusevicius, V., Ottoy, S., Roelens, J., Sing, L., Thomas, A., Meerbeek, K.V., Verweij, P., 2018. Practical solutions for bottlenecks in ecosystem services mapping. One Ecosyst. 3. https://doi.org/10.3897/oneeco.3.e20713.

Persoon, G., Minter, T., 2011. Code of Conduct for Working with Indigenous and Local Communities. Tropenbos Int., Wagening.

Plieninger, T., Dijks, S., Oteros-Rozas, E., Bieling, C., 2013. Assessing, mapping, and quantifying cultural ecosystem services at community level. Land Use Policy 33, 118-129. https://doi.org/10.1016/j.landusepol.2012.12.013.

Price, R., 2002. First-Time: The Historical Vision of an African American People. University of Chicago Press.

Price, R., 1975. Saramaka Social Structure: Analysis of a Maroon Society in Surinam. Institute of Caribbean Studies, University of Puerto Rico.

Ramirez-Gomez, S.O.I., Brown, G., Verweij, P.A., Boot, R., 2016. Participatory mapping to identify indigenous community use zones: implications for conservation planning in southern Suriname. J. Nat. Conserv. 29, 69-78. https://doi.org/10.1016/j.jnc.2015. 11.004 .

Ramirez-Gomez, S.O.I., Brown, G.G., Fat, A.T.S., 2013. Participatory mapping with indigenous communities for conservation: challenges and lessons from suriname. Electron. J. Inf. Syst. Dev Ctries 58.

Ramirez-Gomez, S.O.I., Martínez, C., 2013. Participatory GIS: indigenous communities in Suriname identify key local sites. ESRI 35, 1.

Ramirez-Gomez, S.O.I., Torres-Vitolas, C.A., Schreckenberg, K., Honzák, M., Cruz-Garcia, G.S., Willcock, S., Palacios, E., Pérez-Miñana, E., Verweij, P.A., Poppy, G.M., 2015. Analysis of ecosystem services provision in the Colombian Amazon using participatory research and mapping techniques. Ecosyst. Serv. https://doi.org/10.1016/j. ecoser.2014. 12.009.

Ramirez-Gomez, S.O.I., Verweij, P., Best, L., van Kanten, R., Rambaldi, G., Zagt, R., 2017. Participatory 3D modelling as a socially engaging and user-useful approach in ecosystem service assessments among marginalized communities. Appl. Geogr. 83, 63-77. https://doi.org/10.1016/j.apgeog.2017.03.015.

Ribot, J.C., Peluso, N.L., 2003. A theory of access*. Rural Sociol. 68, 153-181. https:// doi.org/10.1111/j.1549-0831.2003.tb00133.x.

Rodríguez, J.P., Beard Jr., T.D., Bennett, E.M., Cumming, G.S., Cork, S., Agard, J., Dobson, A.P., Peterson, G.D., 2006. Trade-offs across space, time, and ecosystem services. Ecol. Soc. 11, 28.

Shackleton, C., Shackleton, S., 2004. The importance of non-timber forest products in rural livelihood security and as safety nets : a review of evidence from South Africa. South Afr. J. Sci. 100, 658-664.

Sikor, T., Lund, C., 2009. Access and property: a question of power and authority. Dev. Change 40, 1-22. https://doi.org/10.1111/j.1467-7660.2009.01503.x.

Sikor, T., Nguyen, T., 2007. Why may forest devolution not benefit the rural poor? Forest entitlements in vietnam's central highlands. World Dev. 35, 2010-2025. https://doi. org /10.1016/j.worlddev.2006.11.011.

Stichting voor Bosbeheer en Bostoezicht, 2019. National Land Monitoring System of Suriname-Gonini.

Stichting voor Bosbeheer en Bostoezicht, 2016. Bosbouw Sector analyse. Paramaribo.

Syrbe, R.-U., Walz, U., 2012. Spatial indicators for the assessment of ecosystem services: providing, benefiting and connecting areas and landscape metrics. Ecol. Ind. 21, 80-88. https://doi.org/10.1016/j.ecolind.2012.02.013.

Torpey-Saboe, N., Andersson, K., Mwangi, E., Persha, L., Salk, C., Wright, G., 2015. Benefit sharing among local resource users: the role of property rights. World Dev. 72, 408-418. https://doi.org/10.1016/j.worlddev.2015.03.005.

Turkelboom, F., Leone, M., Jacobs, S., Kelemen, E., García-Llorente, M., Baró, F., 
Termansen, M., Barton, D.N., Berry, P., Stange, E., Thoonen, M., Kalóczkai, Á., Vadineanu, A., Castro, A.J., Czúcz, B., Röckmann, C., Wurbs, D., Odee, D., Preda, E., Gómez-Baggethun, E., Rusch, G.M., Pastur, G.M., Palomo, I., Dick, J., Casaer, J., van Dijk, J., Priess, J.A., Langemeyer, J., Mustajoki, J., Kopperoinen, L., Baptist, M.J., Peri, P.L., Mukhopadhyay, R., Aszalós, R., Roy, S.B., Luque, S., Rusch, V., 2018. When we cannot have it all: ecosystem services trade-offs in the context of spatial planning.
In: Ecosyst. Serv., SI: Synthesizing OpenNESS, pp. 566-578. https://doi.org/10. 1016/j.eco ser.2017.10.011.

Ward, C., Stringer, L., Holmes, G., 2018. Changing governance, changing inequalities: protected area co-management and access to forest ecosystem services: a Madagascar case study. Ecosyst. Serv. 30, 137-148. https://doi.org/10.1016/j.ecoser.2018.01. 014. 